\title{
THE INFLUENCE OF ACCELERATION ROTATION STIMULATION ON SERUM POTASSIUM
}

\author{
By \\ T. NOIRI

\section{From the Department of Oto-Rhino-Laryngology, School of Medicine Osaka National University (Director: Prof. T. Hasegawa)}

By means of Prof. Hasegawa's accelerating rotation apparatus, observation was made of the effects upon the serum potassium caused by the labyrinth stimulus and also the effects of them by sodium bicarbonate solution.

In this experiment, normal dogs bilaterally labyrinthectomized dogs and the dogs to which sodium bicarbonate solution, had been injected all un-anaesthetized, were brought under the influence of accelerating rotation stimulus for 15, 30 and 60 minutes and the blood samples were collected every hour to be tasted for the content of serum potassium with Cobaltinitrite method. The following results were obtained.

1) In the normal dogs, the accelerating rotation stimulus caused a considerable, though temporary, increase of the potassium. In other words in the $15 \mathrm{~min}$. stimulus, the level of potassium reached its peak within 10 minutes after the application of the stimulation and in the 30 and $60 \mathrm{~min}$. stimulus, the potassium level reached to the maximum immediately after the test. Then it tapered off with the lapse of time. The highest mark of all was reached in $60 \mathrm{~min}$. test.

2) The dogs which had been given intravenous injection of $2 \mathrm{cc}$ per $\mathrm{kg}$ of sodium bicarbonate solution 2 or 3 days before the experiment or the dogs had been labyrinthectomized on both side a day before were tested likewise. Neither showed no such conspicuous change in the potassium content as shown in the normal dogs, irrespective of the length of the stimulation time. The difference of the potassium content during and after the stimulation upon each group of dogs with this accelerating rotation apparatus was closely measured and the conclusion was made that during the stimulation an increase was observed and after the test the content reduced to the original level with the influence of reparation.

On the basis of the above experiments, it is prsumed that the accelerating stimuli bring about sympathetic nervous disorder through labyrinth and the change in the amount endorses the assumption that the said solution will prevent the motion sickness.

\section{加速迴転刺戟の血清カリウムに及ぼす影響}

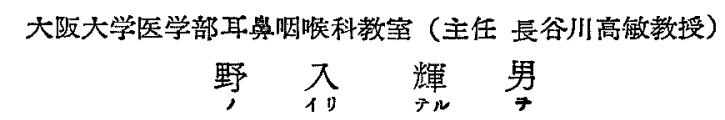

目次

1. 緒言

2. 交献的洘察

3. 実験力法

4. 実験成綪

章 1 虽 対照実酸群
第1節 探血による影饅

第 2 節 重䨪泩射による影響

第 2 章 正 常 群

第 1 節 正常 15 分制戟群

第 2 節 正常 30 分楋战群

第 3 節 正常 60 分刺就群 


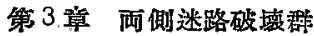

第1 節 迷路破液 15 分制戟群

第 2 節 迷路破壦 30 分战戟群

第 3 節 迷路破㙲 60 分刺戟群

第4 章 重曹注的群

第 1 節 重曹注射 15 分剌韩

第 2 節 重曹注射 30 分跊战啸

第3 節 重曹注射 60 分制战群

第 5 章 加速趈檕刺戟中及び刺战後の鼣察

第1節 対照增減率

第 2 節 正常群增減率

第 3 節 迷路破流群の増減率

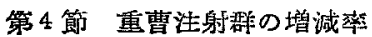

5. 総括及び考按

6. 結語

7. 参考交献

\section{1.緒言}

乗物の最は，人体が長時間文は激しい動摇に会う場 合, 覀心や澏叶等の不快な諸現象が起るるので, 古代の ギリシャ時代より交献に見られる所である.上来多数の 人ヶにより，臨床的，実験的研究が行われてきたが，加 速度を伴う動摇は耳迷路を介して生体に自律神経失調と い5影暨を及ぼすことが注目され，前庭迷路と植物神経 系との間に遙接な関係があることが雕明されてきた。こ の乗物の最すなおち加速度病は高濃度重曹水の静脈内注 射によつて予防されることは，長谷川教授により発見さ れた。これは重曹水注射によつて内耳の耳石機能が阻止 せられ，乗物の動摇の際に発生する加速度刺战が慟きか けなくなりここの刺战で起される震が防止されるからで ある、私は今回加速度殊に加速迴転刺㦸が生体の血清力 リッムに及ぼす影響と，高湴度重軕水静注の加速度予趽 作用機転について観察を行つたのである。

\section{2. 文献的考察}

加速度を伴5動摇の生体に及ぼす影響については徉来 いろいろの観察及び、種々の学説がある. 先づ船量につ いては古くから既にギりシャの医聖 Hippokrates の時 代に身体の擓乱せられた状態であると述べられている。 その外種々の説が唱えられている・すなわら恐怖説，布

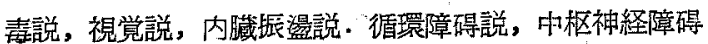
説，更には平衡障碍説等が言われたが，いつれる臨床的 な樭察から推察されたもので，実験医学的な基礎を欠い ている.これ等の中 Pollard (1872) Carpenter, Abrahamz (1874) は灭衡障碍説总晿え，内耳の意義を重視
した・また Flourens（1824）は身体平衡と迷路の関 係に就いて述べたが，James（1882）以麗留者が船最に 躍りにく〉，Reynold（1884）は化膿性中耳炎を経過し た者は屬々船最を免れることを報告した，実験医学に基 碄を置、た学説として拄目されるのは Kreidl (1905) の説で, 両側迷路剔出あるい:両側聴神経甽䉼動物では 船最症状をきたさないことを証明した。その後 Bárány （1910）は前庭刺皒症状と船最と性類似しており，船暈 は内耳の異常刺㦸によつて誘発されると述べる等, 迷路 刺㦸を迴つて多くの実験が行われたが，その結果が必ず しも一致しなかつた・斯情に内耳は船最の発生に大きな 役割字演じていることが稙を報告されている。

乘物の最の実験的研究として，長谷川教授忧従来の実 験成績には迷路刺㦸方法に不備のある事を認め，連続昇 降装埴を考案になられ，これを用いて家束に直線加速度

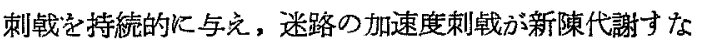
わち, 血圧, 血液の諸性状, 体温, 呼吸, 尿の性状, 消

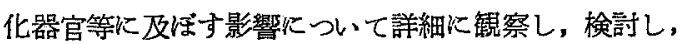
加速度病なる概念を磪立された。

そしててその本態は交感神経緊張による自律神経機能障 碍であると述へられている.すなわら加速度による迷路 刺㦸実験として古川（林）（1941）は迷路性の乎吸運動 抑制を，邀藤 (1940) は迷路性の体温の下降を，高井 （1943）は血圧の上昇をきたすと報告した．消化器系に 牧いては柴田 (1943) は迷路刺战による胃腸運動の抑制 を認め，大川内（勝）（1951）は迷路性澏吐の実験で幽

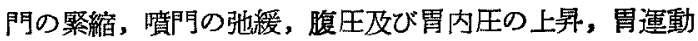
の抑制と胃トーヌスの減退を認め，これ等の嘔吐現象は 主として交感神経緊张性現象であることを明かにした。 又尿に就いては前田（豊）（1944）は加速度刺㦸により 尿量の減少, 比重の増加, 総空荎量の増加, クレアチン 及びタレアチニン量の増加を認めることを報告した． 更に迷路刺战が血液に 及代す影響に就いて古川（隆） （1937）は長谷川式昇降器を用いてこれにより迷路性

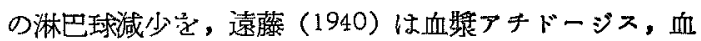
糖の著明な增加，赤血球沈降速度のや〉促進を，伊東 （1943）は血獎カルシウム量の減少，血液凝固時間の促 進を報告した：又年田（実）（1952）は血獎蛋白の増加 ならびKアルブミン・グロブリン比の_七笔することを報 告した．また小西（1949）は家鬼について迷路刺㦸によ る脳循澴の減少, 未梢循睘の堌加, 門脈彔統の充血, 筱 臓循環の增加を認め, 野副 (1942) は家鬼の迷路刺㦸又 は迷路盟置を行うとカルショムは減量しカりウムは增量 
すること是記薣した。

论に迷路破壊方身体に与兄る変化火就いて, 柴 (1929) は体温の低下を，西端 (1929) 岡林 (1937) は鸭, 家鬼 で片側迷路破壊後の副督重量の增加を，瀬尾（1934）は 鳵で片側迷路破壊後の副腎重量の軽微な増加を，後藤 （1932）は迷路破壊による㳙肉稦原質量の減少を, 藤崎

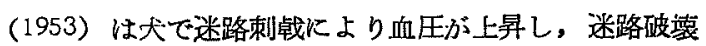
によっては変化がないことを報告した。一方, 前庭迷路 の刺㦸感受部位については古来 Mach-Bruer の仮説が あり，位置の变化と直線運動は前庭部で，廻転運動は三 半規管部で感受せられ，耳石膜のずれ及び半規管淋巴流 動が原因とされてきた. 次いで Magnus 欧 de Klyen は Wittaack の遠心廷転法化より耳石膜を涂離し， 位置の変化は前庭部で，迴転及び直線運動は共に三半規 管で感受せられると提唱した。これ対し長谷川教授 （1931）は彼等の実験の誤りを指摘し，半規管で感受さ れるものは廻転運動つみであり，直線運動は前庭の耳石 器官に㨟いて感受されること定実験的に決定し, 更に位 置の変化は内淋已の静水仕によると反論された.

加速度病の本態は，迷路の加速度刺战によつて起され る交感神経緊張性の自律神経㙨能障碍として解明された

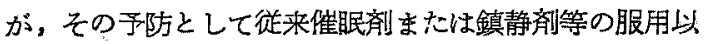
外方法がなく，交通機関の発達に伴い，乗物の最に多く の人々が悩まされていた・長谷川教授 (1943)は7\%重 曹水の静脈内注射が耳石を溶解せしめ, 迷路の加速度刺 㦸に対する感受性を弱めることにより加速度病を䂆方し 得ることを飤案せられた。藤崎 (1947) が 474 名の兵士 につきこの注射を試み, 輝かしい成果を収めて以来, 重 曹注射の効果の持続的であることが認められ，その後豊 島 (1950) 羊田 (哲) (1954) 等の追試方続々と報告され ている.なお最近長谷川教授（1954）は耳石基磷物質か 重曹水によつて变化を受沛ることを証明された。すなわ ち蛙の耳石を生理的食塩水に入れ，高温に㗢かせると， 耳石基礎物質の凝固に上り炭酸カルシウムの結晶が黒褐 色の包被に包まれているのが見られ，耳石を重曹水沉入 れた場合，基碗物質が溶解せられ，高温を働かせても包 被を失つた孷酸うルシッムの結晶のみが見られた。この 溶解により，慣性に対する緩衝相ができて加速度刺战が 防止されると発表された。

先述の長谷川教授が帣案された, 直線邆動の動摇を起 す連続昇降置とは別に，1948 年創案になる角並に遠 心力加速度を加えた特製の長谷川式加速迴転装置を用い ての研究では, 古代 (1953) の家鬼眼圧, 眼球軍動办
ぽす影響，後藤（1953）の家鬼体重，尿，顀便，叠孔。 迷路反射の観察, 内耳及び頸部交感神経, 迷走神経節っ 組䋐学的研究, 長尾 (1955) の犬血中アドレテリン量つ 变化, 松山 (1955) の家鬼呼吸運動の变化, 前田 (1956) の犬゙血清粘稠度 及び血中総 ニレステリン量に 及汸与影 帮，毛利 (1955) の血清蛋白の砳究，王 (1955) の犬血 中副腎皮質ホルモン分必量の变化, 谷口（1956）の犬血 獎中ビタミンA の研究, 上善 (1956) の犬血清カルシ ウム量の検索, 赤埴 (1956) の犬胃液に関する実験, 山 川（1956）の象心臓に及ぼす影響，堀内（1957）の大及 び种の血液水分量の消長等についての報告があり，いす れる交感神経緊張性の変化を認めている. 最近, 藤踦

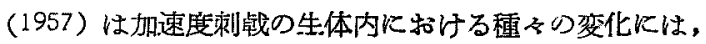
Reparations-ersheinung が大きく関与するものであ り, 従つて交感神経緊張性の諸街候に混じつて副交感神 経緊帳性の諸徴侯す現れて来ることを重視した。それ故 に純粋に迷路に対する加速底刺㦸の影留を観察するるたう

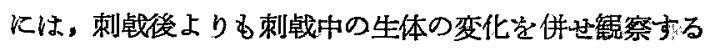
ことが重要であると発表されて括りこの主張従って も討索の歩を進めた。

告体内血清カリゥムの消長は複雑であり, 生理的要因

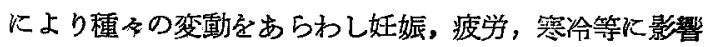
され易いことが古くより知られており又病的状態に和け る研究もいろいろ報告されてて抽る. Dieckmann (1952)

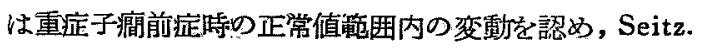

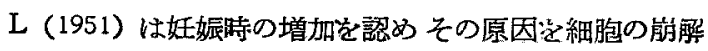
殊に赤血球の崩解と組織中これの移行するためたと述 ベ, Berg. qvist (1952) はこれに反して䉓解質低下を 主唱している. Tena Molera (1937) は娃娠覀阻の場 合，唀圧の变化炕より血中 $\mathrm{K} / \mathrm{Ca}$ が大きくなり，塩 類, 胥白分子結合の状態が不良となり蛋白崩解远起して 湢吐中枢を刺战すると発表し，又一方妊娠末，訛は血液 中のカルシゥム欠乏とカリゥムの増加を認め，交感副交 感神経の與奮性に影響を及隹し，直流電流に対する筋肉 及び神経の 興謧上犁によりこれを証明している。成田 （1956）は血圧下降時の血滂カリウムの娍少とアアドレ

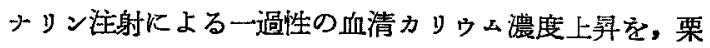
栖 (1955) は放射線照射に上る家象血清カリウムの增量 を, 東条 (1955) ば血糖の変化と血清カリゥムつ変動を 認め, 富田 (1955) は卵白アルブミン等による家冤の全

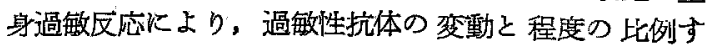
るカリゥムの变化を実験している. Talbot (1943) は Addison 氏病の血清カリゥムの增加諗め, 副腎皮質 ホルモンのカリゥムに対する関係を重視し, Desoxyco- 
rticoșteron が $\mathrm{K} / \mathrm{Na}$ 平衡に主作用を司ると発表して かる、環境温度による影響としては，小川（1955）小林 （1955）は血清カリゥムが冬期多く，夏期に少いこと学， 原島（1953）、血清カリゥムの变動と季節的変動の自律 神経緊張説すなわら，夏期は副交感神経緊張に，冬期は 交感神経緊張に傾き血清カリウムの増加を見ると述べ， これを交感神経部分剔出による, 血清カリゥムの低下減 少を認めることにより契証している。また Selye 等に よりカリゥムの調整は副腎䯣質の内敃泌機能が関係して ちり，更に自律神経系も大きく関与していると述べてい る・

\section{3. 実験方法}

1) 奏験動物

実験動物は $8 \mathrm{~kg}$ 以上の成犬を選び，性は洘蕆しなか つたが，弤脈犬，授乳中心睢犬及び病犬悇みした。 そ

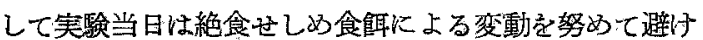
るようにした，実驗の季節は敩寒，炎暑を避计室温 15 〜30 $\mathrm{C}$ 内外とした.

2) 迷路破䱣

迷路の破壊は耳瑴附着部の前方で軟骨部外耳道学切断 し，続いて骨部外耳道を経て鼓膜に達し，これを破つて 鼓空を開放し，棈円密，鼓室岬を明視し次いで小鋭题で

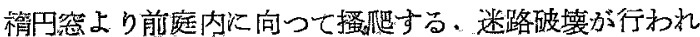

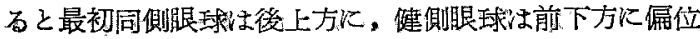
し，次いで健側们尚？著明な眼振をきたす一側迷路佊

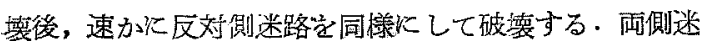
路が完全火破故されると前記のよ5な一側迷路破壊の際 に見られた諸症状は消退するが，な打不安定な状態にす

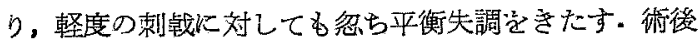
特辟の飼育箱に入れ，翌日実験に供した。

3) 重曹注射

$7 \%$ 重曹水学 $2 \mathrm{cc} / \mathrm{kg}$ 宛, 各成犬の後胶大蓝微静脈 より注射した．重曹注射群の実験は注射後少くとも2日 以上を経た動物で行われ，血液气の他に及ぼす重曹水の 一過性影響を避けた。

4) 採血注

採血は肢静脈より行い，採血回数は各実騟とも6回と し、できるだけ採血によりカリウム量の变動袁梅力少な く京るよう注聕した。

5) 動物の固縛

成犬の固縛は，廻転板上飞背位に且つその体軸が廷枟 板の直堡に一致し，頭部を外側にさけて四肢を箱縳し次 いで頭部艺固定した。

\section{6) 加速迴転装置}

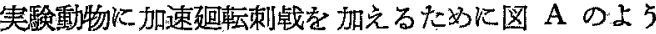

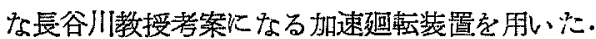

国

A
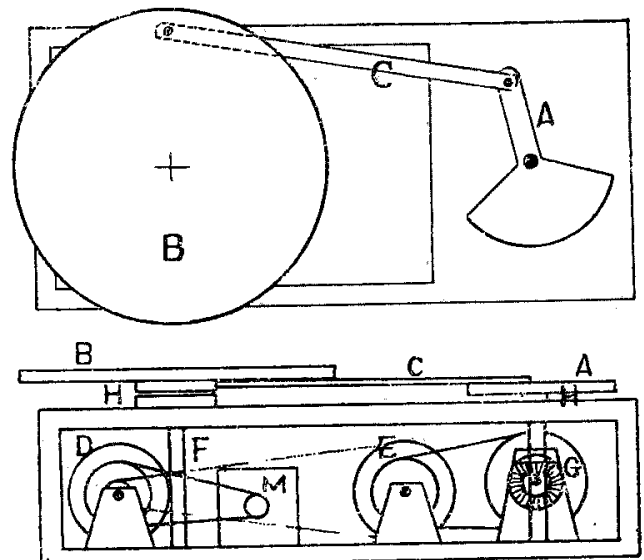
M; モーター
$E: 7^{a}-1-$
A, $C ;$ 踠
F：三計
$B$ ：角加速度标
G: 粠找-

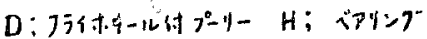
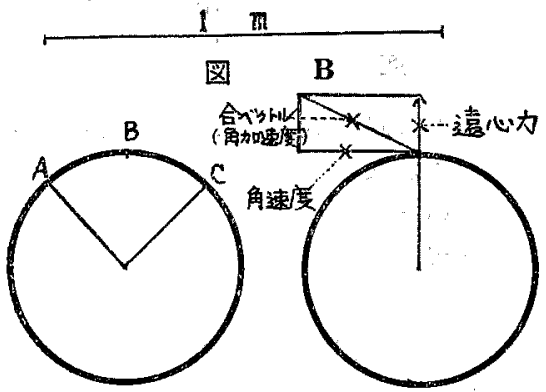

图
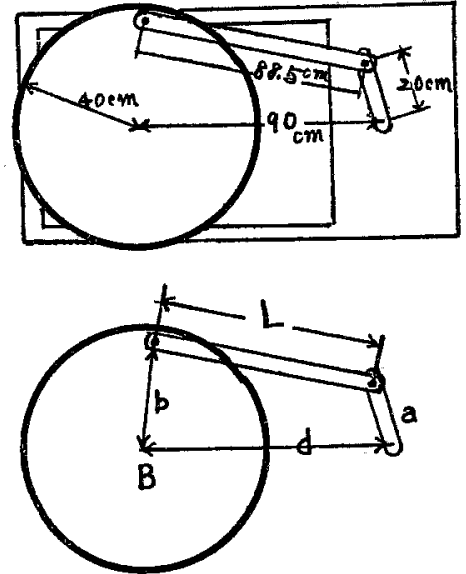
すなわち图 A に示すように装置内のモーター（M) の迴転によりでルトで連結された各プーリー (D, E) は迴転し，それが各笠形ギャ一（G）によってシャフト (F) の廷転となり，その一端に荘置された腕 $(A, C)$ の運動となり，更に腕 (C) の附着する円板 (B) の往 復廻転運動となつて現われる・すなかちモーター（M) の迴転学毎分 45,60，90 回 3段にする事ができ，円板の

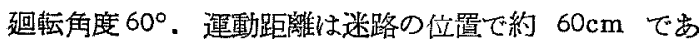
る.な打本装置の特色は, ブランコ運動を水平面に描く ことができるわけで，従来の迴鞋運動では見られなから た往復廻転運動を営むことができ，廹転方向及び加速度 が絶党ず变化するもので長時間に亘つて腼㨁学行い，同 路に䢙転運動によつて角加速度，遠心力加速度刺战の影 響艺も検討することができるうけである・すなわち本装 固は加速度発生の点に沶いてては従来の迴転装置と甚だ趣 を巽にしている，

今 $b>a$ として $a, b, d ， 1$, を一定化して $a$ を等速 迴転させると迴転板 (B) にる亦等速迴転運動を営ませ ることができる・今（B）の廻転角变日で現わすと

$$
\begin{array}{ll}
\text { 角速度 } & W=\frac{d \theta}{d t} \\
\text { 角加速度 } & L=\frac{d^{2} \theta}{d^{2} t^{2}}
\end{array}
$$

となる・更に遠心力及び角加速度による面線加速度を夫 \& Ac, $\mathrm{Aa}$ とすれば

$$
\begin{aligned}
& \mathrm{Ac}=\mathrm{rW}^{2} \\
& \mathrm{Aa}=\gamma \mathrm{L}
\end{aligned}
$$

となり実際に笑験中の犬の迷路の位置が例壳ば廻転板の 中心から $60 \mathrm{~cm}$ の距離にあれば，廻転角の在右两端に 扣ける筩速度最大值 (Aa max.) は夫ね $1.02 \mathrm{~g}$ 及び $0.63 \mathrm{~g}$ となり, 遠心力最大值 (Ac max.) は $0.40 \mathrm{~g}$ と なる.さてその迴枟に当つては遠心力は常に円板の半径 方向に，角速度生切線方向に㗢き，互值角の関保儿あ り，両者の合べクトルが実際にからつてくる角加速度と なる. その両者の関係化一方が0となつた場合，他方が 最大值に近〉両者の合べクトルは变化沓ず方向は終始変 化することになる。 今仮に図 $\mathrm{B} の \mathrm{~A}$ 点及び $\mathrm{C}$ 点を 夫々迴転角 $(\theta)$ の両端とし， $\mathrm{B}$ 点をその中心点とする 時， $A$ 点及び $C$ 点での遠心力 $(A c)$ は 0 と成るのに 反し角加速度（Aa）你最大となる，これと反対に $\mathrm{B}$ 点 では角加速度は最小で遠心力は最大となるわけである。

7) 定 量 法

血清カリウムの定芘法は種々岁るが，今回は Cobaltinitrite 法を用いた。

すなわち血清 $1.0 \mathrm{cc}$ を目盛付小遠心管に取り, Nat- rium aceticum の半館和液 $1.0 \mathrm{cc}$ を加六混和する.次火 新しく㴧過した Natrium Cobaltinitrite 試楽の $1.0 \mathrm{cc}$ 滴ず混和乙乍战下, 45 分間室温放置後 $2.0 \mathrm{cc} の$ 蒸溜水で管内壁を洗い, 込み, 2000 廻転で 15 分間德心：上 澄を搭てる. 15 分間罳紙上に斜倒し，液を流出せしめ，

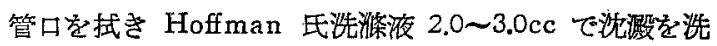
w，15 分間遠心後上記の如く上澄を唅て 且っ流出せ乙 め, 更飞 70\% Ethyl Alchol 2.0 -3.0cc を入れ，碃子 棒で沈澱を隐拌し，1.0〜2.0cc の Ethyl Alchol で棒 を洗、迈み，5分間遠心後上澄唅て流出せしめる。こ の操作を反覆後，次に蒸溜水 $2.0 \mathrm{cc}$ 沈澱に加方，管を 約 15 分間煮沸水浴につけ，硝子桡で沈搌を壊し溶解せ しめ，2.0３.0cc の蒸溜水で棒之洗い込み，更に 5 分間 煮沸水浴につける．沈澱は完全に溶けてから室温に冷却 後, 1.0cc の Cholin Chloridum (1.0\%) を加光, 次 いで Kalium Ferrocyanide 稀釈液 (4.0\%) 1.0cc を 加劣る.この操作を行うと液は篮光色を呈した緑色を呈 する。

一方他の試験管に蒸溜水 $1.0 \mathrm{cc}$. Cholin Chloridum (1.0\%) 1.0cc. Kalium Ferrocyanide 稀釈液 $(4,0 \%)$ $1.0 \mathrm{cc}$ をこの順に入れて混和，この溶液を Blank とす る.被検液と Blank 両試験管内容が各 $10 \mathrm{cc}$ 宛となる よ5目盛まで蒸溜水を加点，光電比色計で比色する.今 回は伊藤式光電比色計を用い,フィルターは波長 $420 \mathrm{~m} \mu$ を使つて定量した。

\section{4. 実 験 成績 \\ 第 1 章 対照実験群}

第 1 節 採血による影響

刺傤実験に 先だち，対照として正常犬につき，固穗 前, 固縛直後, 10 分, 30 分, 60 分, 更に 90 分迄経過 を追つて血清カリゥム量 (以下血清 $\mathrm{K}$ 量と略す) を定量 し，固縛並びに採血による影響を観察した. $(\mathrm{mg} / \mathrm{dl}=$ milligram per deciliter)

実験 1 動物番号 No. 1 各 体重 $8.5 \mathrm{~kg}$

No. 1 の正常大の K 量は固䌧前 $16.3 \mathrm{mg} / \mathrm{dl}$ K対 $L$, 固縛直後では $16.7 \mathrm{mg} / \mathrm{dl}, 10$ 分後 $16.5 \mathrm{mg} / \mathrm{dl}, 30$ 分後 $16.1 \mathrm{mg} / \mathrm{dl}, 60$ 分後 $15.9 \mathrm{mg} / \mathrm{dl}, 90$ 分後では $16.1 \mathrm{mg}$ /dl を示した・動物は終始元気であった。

実騟 2 No. 2 \& $11.5 \mathrm{~kg}$

No. 2 の K 量は固絤前 $17.8 \mathrm{mg} / \mathrm{dl}$ の子のが, 固䋘 直後では $17.2 \mathrm{mg} / \mathrm{dl} .10$ 分後, 30 分後共に $17.0 \mathrm{mg} / \mathrm{dl}$, 60 分後 $16.7 \mathrm{mg} / \mathrm{dl}, 90$ 分後では $16.3 \mathrm{mg} / \mathrm{dl}$ 之や上減 少を示したすの今，注目すべき範囲内のるのと思われな 
かつた.な特動物は若干元気がなかつた。

実験 3 No. 3 o $12.5 \mathrm{~kg}$

血清 $\mathrm{K}$ 量は固縛前 $19.2 \mathrm{mg} / \mathrm{dl}$, 固縛值後 $19.6 \mathrm{mg} / \mathrm{dl}$, 10 分後 $19.4 \mathrm{mg} / \mathrm{dl} ， 30$ 分後 $19.0 \mathrm{mg} / \mathrm{dl} ， 60$ 分後 18.8 $\mathrm{mg} / \mathrm{dl}, 90$ 分後では $18.4 \mathrm{mg} / \mathrm{dl}$ と大差なく経過した。 動物は少し近いたが終始元気を保つていた。

宅験 4 No. 4 \& $14.5 \mathrm{~kg}$

血清 $\mathrm{K}$ 䁷は固縛前 $17.2 \mathrm{mg} / \mathrm{dl}$ に対し，固縛直後で は $17.4 \mathrm{mg} / \mathrm{dl}, 10$ 分後 $17.8 \mathrm{mg} / \mathrm{dl}, 30$ 分後 $17.4 \mathrm{mg} / \mathrm{dl}$, 60 分後，90 分後は共に $17.0 \mathrm{mg} / \mathrm{dl}$ 示した。動物は 至極元気でおつた。

小 括:

以上 4 例を総合して見るのに血清 $\mathrm{K}$ 量の平均值は， 固縛前 $17.6 \mathrm{mg} / \mathrm{dl}$, 亿対し, 固縛直後には $17.7 \mathrm{mg} / \mathrm{dl}$, 10 分後, 30 分後には共に $17.6 \mathrm{mg} / \mathrm{dl}$, 90 分後 $16.9 \mathrm{mg}$ /dl と極く少量の減少を示したが，その間の差はあるい、 は誤差範囲の中に入るのではないかと思われる程度であ つた.これにより正常大の血清 $\mathrm{K}$ 量は採血によつて著 しい変動を示さないことが観察された。图表に示せば次 の如くである(第1表, 第 1 図).

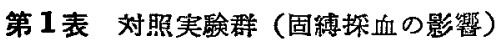

\begin{tabular}{|c|c|c|c|c|c|c|c|c|}
\hline 克物息㝵 & $1 \pm$ & 体害( $\left(x_{f}\right)$ & 掰回 & 正隹 & $10^{\circ}$ & $30^{\circ}$ & $60^{\circ}$ & $90^{\circ}$ \\
\hline No I & $\hat{\sigma}$ & 8.5 & 16.3 & 16.7 & 16.5 & 161 & 15.9 & 16.1 \\
\hline $\mathrm{NO} .2$ & $\delta$ & 11.5 & 17.8 & 17.2 & 170 & 170 & 16.7 & 16.3 \\
\hline NO3 & 5 & 12.5 & 192 & 196 & 194 & 19.0 & 18.8 & 18.4 \\
\hline N 0.4 & f & 14.5 & 17.2 & 174 & 178 & 17.4 & 17.0 & 17.0 \\
\hline 平可犆 & & & 176 & 17.7 & 176 & 17.6 & 171 & 16.9 \\
\hline
\end{tabular}

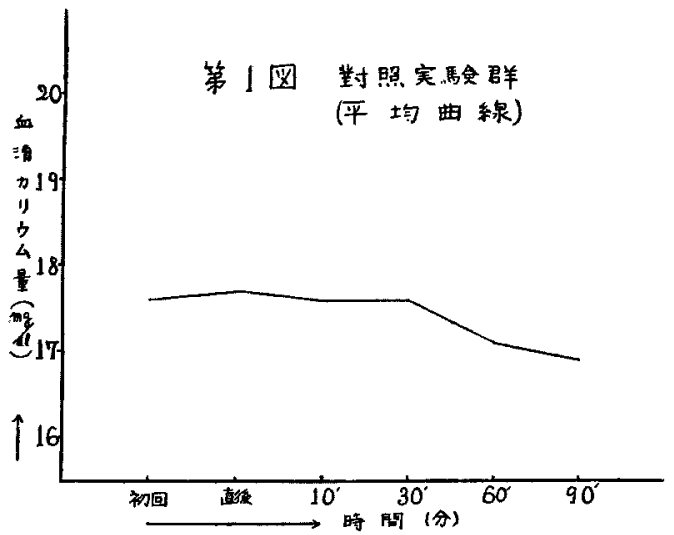

第2 節 重曹注射による影響

重蕾注射が血清 K 量にいがる影響を与学るがつ いて観察するためPro. kg 2cc の7\% 重曹水を静注
乙, 注射前, 注射直後, 10 分後, 30 分後, 60 分後, 90 分後迄，一部の実験動物では 24 時間後の採血をして定 量した.

実験 5 No. 5 o $9.5 \mathrm{~kg}$

注射前 $19.6 \mathrm{mg} / \mathrm{d} 1$ に対し，注射直後は $18.8 \mathrm{mg} / \mathrm{d}$ ， 10 分後 $17.6 \mathrm{mg} / \mathrm{dl}, 30$ 分後 $18.2 \mathrm{mg} / \mathrm{dl}, 60$ 分後 $17.8 \mathrm{mg}$ $/ \mathrm{dl}, 90$ 分後では $17.2 \mathrm{mg} / \mathrm{dl}$ を示し時間の経過と共に 減少する傾向が見られた.実験中動物は元気であつた。

実駰 6 No. 6 \% $8.7 \mathrm{~kg}$

注射前 $17.2 \mathrm{mg} / \mathrm{dl}$ のものが, 注射直後 $16.1 \mathrm{mg} / \mathrm{d}$, 10 分後 $i 5.8 \mathrm{mg} / \mathrm{dl}, 30$ 分後, 60 分後, 90 分後は共保 $15.6 \mathrm{mg} / \mathrm{d} 1$ を示した，実験中動物は至極元気であった。

実験 7 No. 7 o $12.5 \mathrm{~kg}$

注射前 $17.8 \mathrm{mg} / \mathrm{dl}$ K対し, 注射直後は $17.0 \mathrm{mg} / \mathrm{d} 1$, 10 分後 $16.7 \mathrm{mg} / \mathrm{dl}, 30$ 分後, 60 分後共に $16.3 \mathrm{mg} / \mathrm{dl}$, 90 分後には $16.1 \mathrm{mg} / \mathrm{dl}$ となつた. 実験中動物は少し暴 れた. 動物は最後まで比較的疲労の色が少いよ5に思わ れた。

実験 8 No. 8 o $10.5 \mathrm{~kg}$

注射前 $20.1 \mathrm{mg} / \mathrm{dl}$ のものが, 注射直後 $19.7 \mathrm{mg} / \mathrm{dl}$, 10 分後 $19.3 \mathrm{mg} / \mathrm{dl}, 30$ 分後 $17.6 \mathrm{mg} / \mathrm{dl}, 60$ 分後 18.2 $\mathrm{mg} / \mathrm{dl}, 90$ 分後には $17.6 \mathrm{mg} / \mathrm{dl} .24$ 時間後には $19.8 \mathrm{mg}$ /d1 となり，注射前の值倿近して行つた。動物は終始 元気であつた。

実駩 9 No. 38 \& $10.5 \mathrm{~kg}$

注射前 $19.4 \mathrm{mg} / \mathrm{dl}$ K対し, 注射直後 $17.8 \mathrm{mg} / \mathrm{dl}, 10$ 分後 $17.6 \mathrm{mg} / \mathrm{d}, 30$ 分後 $18.4 \mathrm{mg} / \mathrm{dl}, 60$ 分後む $18.4 \mathrm{mg}$ $/ \mathrm{dl}, 90$ 分後 $18.8 \mathrm{mg} / \mathrm{dl}, 24$ 時間後には $19.6 \mathrm{mg} / \mathrm{dl}$ を 示した. 実騃中動物は若干元気がないように思われた。

小 括:

以上 5 例を総合して見るのに，血清 $\mathrm{K}$ 量の平均値は， 注射前 $18.8 \mathrm{mg} / \mathrm{dl}$ K対し, 注射直後 $17.8 \mathrm{mg} / \mathrm{dl}, 10$ 分 後 $17.6 \mathrm{mg} / \mathrm{dl}, 30$ 分後 $16.8 \mathrm{mg} / \mathrm{dl}, 60$ 分後 $17.4 \mathrm{mg} / \mathrm{dl}$, 90 分後 $17.5 \mathrm{mg} / \mathrm{dl}, 24$ 時間後 $18.7 \mathrm{mg} / \mathrm{dl}$ を示した.こ れにより正常犬の血清 $\mathrm{K}$ 量恃重曹注射によって, 注射

第 2 表 対照実倹群（重曹注射の影留）

\begin{tabular}{|c|c|c|c|c|c|c|c|c|c|}
\hline 现物䂑引 & 性 & 体直 $\left(x_{y y}\right.$ & 注的前 & 注暂很 & $10^{\circ}$ & $30^{\circ}$ & $60^{\prime}$ & $90^{\circ}$ & $24 \Delta t$ \\
\hline NO. 5 & 今 & 95 & 196 & 18.8 & 176 & 18.2 & 17.8 & 17.2 & \\
\hline No. 6 & 우 & 8.7 & 172 & 16.1 & 15.8 & 156 & 15.6 & 15.6 & \\
\hline NO. 7 & 5 & 12.5 & 17.8 & 170 & 16.7 & 16.3 & 16.3 & 16.1 & 16.7 \\
\hline No. 8 & $\delta$ & 10.5 & 20.1 & 19.7 & 19.3 & 176 & 18.2 & 17.6 & 198 \\
\hline N 0.38 & 우 & 10.5 & 19.4 & 17.8 & 17.6 & 18.4 & 18.4 & 18.8 & 19.6 \\
\hline 平均值 & & & 188 & 178 & 176 & 16.8 & 17.4 & 17.5 & 18.7 \\
\hline
\end{tabular}




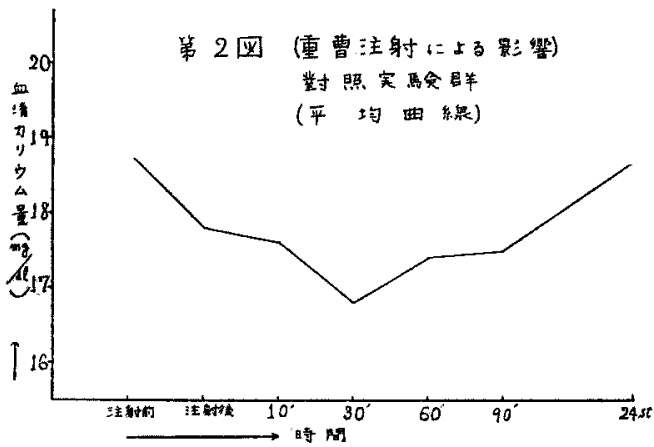

直後から漸次減少する傾向が見られるが，24時間後に は注㴬前の值に復することが観察された。图表に示 せば次の如くである（第2表，第2図).

\section{第 2 章 正 常 群}

第 1 節 正常 15 分剩㦸群

無麻酷の成犬に 15 分間の 加速迴転刺战を加元，剌战 前及び刺㦸直後より90 分後迄の経過を観察し.た。

笑験 10 No. 9 o $8.3 \mathrm{~kg}$

血清 $\mathrm{K}$ 量は刺㦸能 $17.0 \mathrm{mg} / \mathrm{dl}$ のるのが刺战值後 $17.6 \mathrm{mg} / \mathrm{dl} ， 10$ 分後 $19.0 \mathrm{mg} / \mathrm{dl}$ と急增し，30 分得 16.3 $\mathrm{mg} / \mathrm{dl}, 60$ 分後 $16.7 \mathrm{mg} / \mathrm{dl}, 90$ 分後では $17.2 \mathrm{mg} / \mathrm{dl}$ を 示し，刺㦸前の值に復した。実験中動物は終始元気であ つた.

実験 11 No. 10 f $9.5 \mathrm{~kg}$

刺钱前の血浩 $\mathrm{K}$ 量はを $18.6 \mathrm{mg} / \mathrm{dl}$ 示したが，刺㦸 直後では $19.2 \mathrm{mg} / \mathrm{dl}$ とや上上昇し, 10 分後 $20.5 \mathrm{mg} / \mathrm{dl}$, 之增加乙. 30 分後 $20.1 \mathrm{mg} / \mathrm{d} 1,60$ 分後 $18.8 \mathrm{mg} / \mathrm{dl}, 90$ 分後 $18.2 \mathrm{mg} / \mathrm{dl}$ と減少し, 刺战前の值に接近して行つ た.動物は実験中少し疲労の色が見られた。

実驗 12 No. 11 o $10.6 \mathrm{~kg}$

血清 $\mathrm{K}$ 量は刺战前 $16.7 \mathrm{mg} / \mathrm{dl}$ のものが，刺战直後 $17.8 \mathrm{mg} / \mathrm{dl}, 10$ 分後 $18.6 \mathrm{mg} / \mathrm{dl}$ 々上景し, 30 分後 16.7 $\mathrm{mg} / \mathrm{dl}, 60$ 分後 $17.0 \mathrm{mg} / \mathrm{dl}, 90$ 分後では $17.4 \mathrm{mg} / \mathrm{dl}$ を 示した. 動物は至極元気であった.

実験 13 No. 12 \& $12.5 \mathrm{~kg}$

血清 $\mathrm{K}$ 量は刺战前 $17.6 \mathrm{mg} / \mathrm{dl}$ を示し.たが，刺㦸直 後 $18.0 \mathrm{mg} / \mathrm{dl}, 10$ 分後 $18.8 \mathrm{mg} / \mathrm{dl}$ ，とや上上昇し， 30 分後水は $19.0 \mathrm{mg} / \mathrm{d} 1$ 之最も上昇示し，60 分後 18.2 $\mathrm{mg} / \mathrm{dl}, 90$ 分後 $17.2 \mathrm{mg} / \mathrm{dl}$ と次第に下降する経過をた ぞったな和動物は終始元気であった。

小 括:

これ等 4 例の血清 $\mathrm{K}$ 量平均值をとつて見るに, 刺㦸
第 3 表 正常群（15 分制请）

\begin{tabular}{|c|c|c|c|c|c|c|c|c|}
\hline 勏物繁品 & $1+2$ & 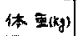 & 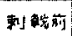 & 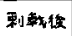 & $10^{\circ}$ & $30^{\prime}$ & $60^{\circ}$ & $90^{\circ}$ \\
\hline N 0.9 & 5 & $8 \cdot 3$ & 170 & 17.6 & 190 & 16.3 & 16.7 & 17.2 \\
\hline N 0.10 & $\boldsymbol{\delta}$ & 95 & 18.6 & 19.2 & 20.5 & 20.1 & 18.8 & 18.2 \\
\hline N 0.11 & $\delta$ & 10.6 & 16.7 & 178 & 18.6 & 16.7 & 17.0 & 17.4 \\
\hline$N 0.12$ & 우 & 12.5 & 176 & 180 & 18.8 & 190 & 18.2 & 172 \\
\hline 平均值 & & & 174 & 18.1 & 192 & 18.0 & 17.6 & 17.5 \\
\hline
\end{tabular}

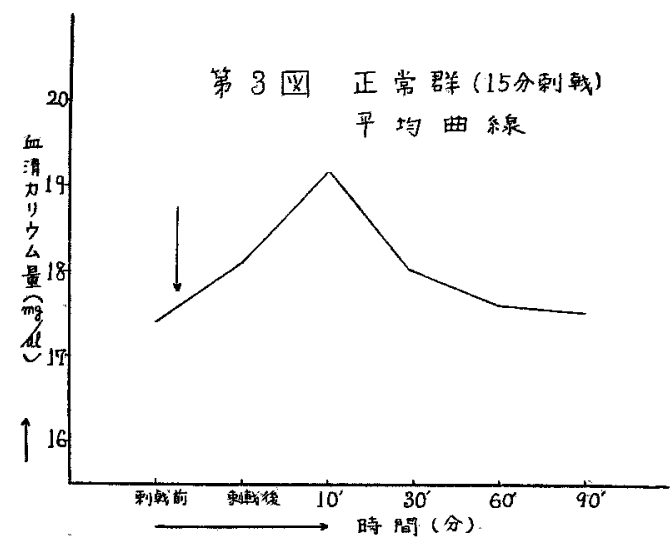

前 $17.4 \mathrm{mg} / \mathrm{dl}$ のものが, 刺战直後 $18.1 \mathrm{mg} / \mathrm{dl}$ そや〉 増加し, 10 分後には $19.2 \mathrm{mg} / \mathrm{dl}$ と最高值を示し, 次い で 30 分後 $18.0 \mathrm{mg} / \mathrm{dl}, 60$ 分後 $17.1 \mathrm{mg} / \mathrm{dl}, 90$ 分後 17.5 $\mathrm{mg} / \mathrm{dl}$ 子徐々に刺㦸前の值に帰る傾向が見られた，図 表に示せば次の通りである（第3表，第3図).

第 2 節 正常 30 分刺㦸群

加速廻転刺㦸を 30 分に延長し. その刺戟の血清 $\mathrm{K}$ 量 に及洁す影響を時間的に検討した。

実験 14 No. 13 \& $10.5 \mathrm{lg}$

刺㦸前の值は $16.5 \mathrm{mg} / \mathrm{dl}$, 刺㦸直後 $16.9 \mathrm{mg} / \mathrm{dl}, 10$ 分 後 $17.2 \mathrm{mg} / \mathrm{dl} ， 30$ 分後 $17.4 \mathrm{mg} / \mathrm{dl}$ と徐々飞堌加し 60 分後 $17.0 \mathrm{mg} / \mathrm{dl}, 90$ 分後 $16.7 \mathrm{mg} / \mathrm{dl}$ 減少した，動物 は実験中少しも疲労の色が見えなかつた。

実験 15 No. 14 우 $12.5 \mathrm{~kg}$

刺战前の血清 $\mathrm{K}$ 量は $20.3 \mathrm{mg} / \mathrm{dl}$, 刺㦸直後 $23.1 \mathrm{mg}$ /dl と急激仩上昇し， 10 分後 $21.1 \mathrm{mg} / \mathrm{dl} ， 30$ 分後 19.4 $\mathrm{mg} / \mathrm{dl}, 60$ 分後 $19.0 \mathrm{mg} / \mathrm{dl}, 90$ 分後 $18.6 \mathrm{mg} / \mathrm{dl}$ 々徐穴

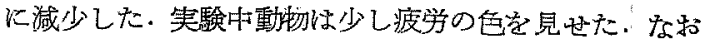
この例では他比して高い值を示した。

実験 16 No. 15 . 古 $9.0 \mathrm{~kg}$

血清 $\mathrm{K}$ 量湟刺㦸前 $18.2 \mathrm{mg} / \mathrm{dl}$, 刺傤直後 $20.5 \mathrm{mg}$ /dl と最高値を示し， 10 分後 $19.8 \mathrm{mg} / \mathrm{dl}, 30$ 分後 20.1 $\mathrm{mg} / \mathrm{dl}, 60$ 分後 $19.4 \mathrm{mg} / \mathrm{dl}, 90$ 分後 $18,0 \mathrm{mg} / \mathrm{dl}$ 之減少 し，次第に刺战椾の值に復帰することが㓋察された。 
小 括：

以上 3 例の平均值をとれば，刺戱前の血清 $\mathrm{K}$ 量は $18.3 \mathrm{mg} / \mathrm{dl}$ を示したが，刺㚌後 $20.1 \mathrm{mg} / \mathrm{dl}$ 子急激に上 昇し， 10 分後 $19.3 \mathrm{mg} / \mathrm{dl}, 30$ 分後 $18.9 \mathrm{mg} / \mathrm{dl}, 60$ 分後 $18.4 \mathrm{mg} / \mathrm{dl}, 90$ 分後 $17.7 \mathrm{mg} / \mathrm{dl}$ 々漸次減少し, 刺㦸前 の值汇接近して行く倾向が見られた．図表汇示せば次の 通りである（第4 表，第4図).

第 4 表 正常群（30 分制戟）

\begin{tabular}{|c|c|c|c|c|c|c|c|c|}
\hline 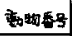 & $r \mid$ & 体重(0g) & 俥敏前 & 剩戙振 & $10^{\circ}$ & $30^{\circ}$ & $60^{\prime}$ & $90^{\prime}$ \\
\hline No. 13 & 5 & 10.5 & 16.5 & 16.9 & 17.2 & 17.4 & 17.0 & 16.7 \\
\hline No. 14 & q & 12.5 & 20.3 & 23.1 & $21-1$ & 19.4 & 19.0 & 18.6 \\
\hline NO15 & $\delta$ & 9.0 & 18.2 & 20.5 & 19.8 & 20.1 & 19.4 & 18.0 \\
\hline 平均估 & & & 18.3 & 20.1 & 19.3 & 18.9 & 18.4 & 17.7 \\
\hline
\end{tabular}

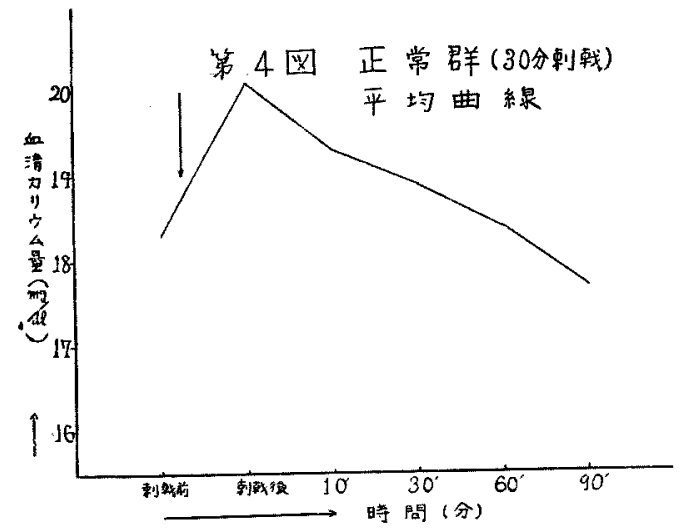

第3 節 正常 60 分刺战群

加速廻転刺㦸を更に 60 分に延長し，その長時間刺㦸 の血清 $\mathrm{K}$ 量に及ぼす影響を覞察した。

実験 17 No. 16 \$ $9.5 \mathrm{~kg}$

刺㦸前の血清 $\mathrm{K}$ 量 $19.4 \mathrm{mg} / \mathrm{dl}$ が刺战直後 $21.8 \mathrm{mg}$ /dl z急増し, 10 分後 $18.6 \mathrm{mg} / \mathrm{dl}, 30$ 分後 $17.6 \mathrm{mg} / \mathrm{dl}$ と壍減し，60 分後 $18.6 \mathrm{mg} / \mathrm{d} 1,90$ 分後 $19.0 \mathrm{mg} / \mathrm{dl}$ と や」上昇を示した，動物証迴転直後少し泣き頭を動かす もすぐ平静となつた。

実験 18 No. 17 \& $12.0 \mathrm{~kg}$

血清 K 量は刺㦸前 $17,8 \mathrm{mg} / \mathrm{dl}$ のものが刺战直後 $20.3 \mathrm{mg} / \mathrm{dl}, 10$ 分後 $20.7 \mathrm{mg} / \mathrm{dl}$ と急増し， 30 分後 19.8 $\mathrm{mg} / \mathrm{dl}, 60$ 分後 $18.8 \mathrm{mg} / \mathrm{dl}, 90$ 分後 $18.6 \mathrm{mg} / \mathrm{dl}$ と洔間 を追うて徐々火娍少した，動物は最後をで平静であつた が，少し疲労の色が見られた。

実験 $19 \quad$ No. $18 \quad 8 \quad 11.5 \mathrm{~kg}$

刺战前の血清 $\mathrm{K}$ 量は $19.2 \mathrm{mg} / \mathrm{dl}$ と示したが刺战直
後 $22.1 \mathrm{mg} / \mathrm{dl}$ と最高値を示し，10 分後 $21.3 \mathrm{mg} / \mathrm{dl}, 30$ 分後 $19.6 \mathrm{mg} / \mathrm{dl}, 60$ 分後 $19.2 \mathrm{mg} / \mathrm{dl}$ と減少を示した が，90 分後には $19.8 \mathrm{mg} / \mathrm{dl}$ と少し上昇を見せた。

な和実験中動物は元気であつた。

小 括：

以上3例の平均值を見ると，刺战前の血清 $\mathrm{K}$ 量は $18.8 \mathrm{mg} / \mathrm{dl}$, 刺战直後 $21.4 \mathrm{mg} / \mathrm{dl}$ と急增し, 10 分後 $20.2 \mathrm{mg} / \mathrm{dl}, 30$ 分後 $19.0 \mathrm{mg} / \mathrm{dl}, 60$ 分後 $18.8 \mathrm{mg} / \mathrm{dl}$ と 滅少し，90 分後 $19.1 \mathrm{mg} / \mathrm{dl}$ と倬加乍ら增加が見られ た. 而してその各時間每の $\mathrm{K}$ 量平均数值は正常 15 分 刺战群，正常 30 分刺战群を遥が上廻つた值を示し刺 战の強さを物語るものと察せられ心（第 5 表，第 5 図）。

第 5 表 正常群（60 分制故）

\begin{tabular}{|c|c|c|c|c|c|c|c|c|}
\hline 重物程昌 & 性 & 体 夏利) & 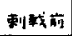 & 刺神推 & $10^{\circ}$ & $30^{\circ}$ & $60^{\circ}$ & $90^{\circ}$ \\
\hline Nol 016 & $\delta$ & 95 & 19.4 & 218 & 186 & 176 & 18.6 & 190 \\
\hline NOI7 & 우 & 120 & 178 & 20.3 & 20.7 & 198 & 18.8 & 18.6 \\
\hline$N O 18$ & 5 & 115 & 19.2 & 221 & 213 & 19.6 & 19.2 & 19.8 \\
\hline 平物值 & & & 188 & 214 & 20.2 & 190 & 18.8 & 191 \\
\hline
\end{tabular}

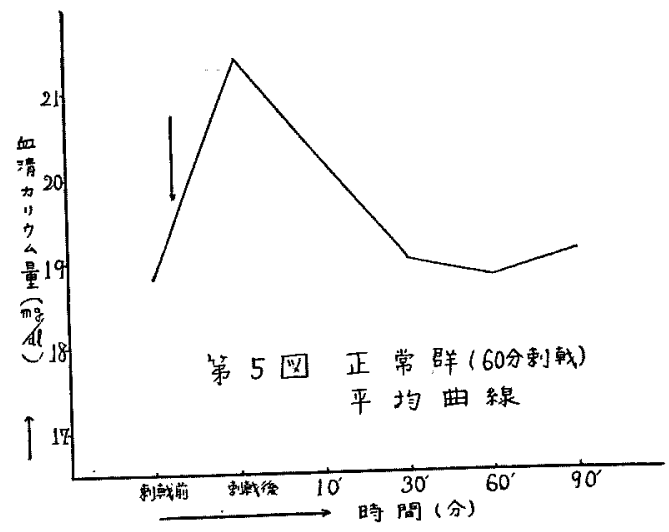

第3 章 而側迷路破壊群

第 2 章机いて正常大に加速迴较刺㦸を与えると，血 清 $\mathrm{K}$ 量の増加を見たが，これ等の変化が果して迷路を

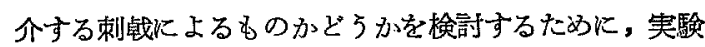
前日両側迷路を破壞した成犬に同倳の実験を試みた。

第 1 節 迷路破壊 15 分刺钱群

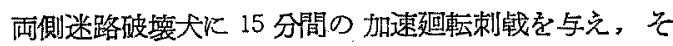
の血清 $\mathrm{K}$ 量汇及涪す影響を観察した。

䒠駼 20 No. 19 \& $12.0 \mathrm{~kg}$

血清 $\mathrm{K}$ 量江刺㦸前 $18.6 \mathrm{mg} / \mathrm{dl}$, 刺㦸直後 $19.2 \mathrm{mg} / \mathrm{dl}$ ， 30 分後 $19.4 \mathrm{mg} / \mathrm{dl}, 60$ 分後 $18.8 \mathrm{mg} / \mathrm{dl}, 90$ 分後 17.6 
$\mathrm{mg} / \mathrm{dl}$ と大差なく経過した. 動物は90 分後に近すくに つれて少しく苦悶の状竟呈し，実験終了後死亡した。

実験 21 No. 20 \% $13.5 \mathrm{~kg}$

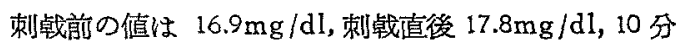
後は $17.4 \mathrm{mg} / \mathrm{dl}, 30$ 分後 $16.7 \mathrm{mg} / \mathrm{dl}, 60$ 分後 $16.5 \mathrm{mg} /$ $\mathrm{d} 1,90$ 分後は $16.1 \mathrm{mg} / \mathrm{d} 1$ を示し, いつ机著しい変動 が見られなく動物は割に平静であつた。

実験 22 No. 21 . 古 $15.0 \mathrm{~kg}$

刺战前の血清 $\mathrm{K}$ 量は $16.1 \mathrm{mg} / \mathrm{d}$ であつたが, 刺㦸 直後 $16.5 \mathrm{mg} / \mathrm{dl}, 10$ 分後 $17.0 \mathrm{mg} / \mathrm{dl}, 30$ 分後 $17.2 \mathrm{mg}$ $/ \mathrm{dl}, 60$ 分後 $16.3 \mathrm{mg} / \mathrm{dl}, 90$ 分後 $16.5 \mathrm{mg} / \mathrm{dl}$ 上㒖少の 増減内で経過した。動物は疲学の色が相当認められた。

\section{小 括:}

上上 3 例の平均值は刺㦸前 $17.2 \mathrm{mg} / \mathrm{dl}$ K対し, 刺战 值後 $17.8 \mathrm{mg} / \mathrm{dl}, 10$ 分後 $17.9 \mathrm{mg} / \mathrm{dl}, 30$ 分後 $17.2 \mathrm{mg}$ $/ \mathrm{dl}, 60$ 分後 $16.6 \mathrm{mg} / \mathrm{dl}, 90$ 分後は $16.7 \mathrm{mg} / \mathrm{dl}$ を示し た.すなかち両側迷路破環犬火 15 分間加速迴転刺战を 与えると，10 分後に僅かに増加するの子で他怡んど 著しい変化を示さなからた（第6表，第6図）.

第 6 表 迷路破堎群 (15 分刺戟)

\begin{tabular}{|c|c|c|c|c|c|c|c|c|}
\hline 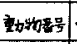 & 性 & 体重(*g) & 俥献前 & 製战特 & $10^{\prime}$ & $30^{\prime}$ & $60^{\circ}$ & $90^{\prime}$ \\
\hline No.19 & $\delta$ & 12.0 & 18.6 & 192 & 19.4 & 18.8 & 18.2 & 136 \\
\hline No.20 & $q$ & 13.5 & 16.9 & 178 & 17.4 & 167 & 16.5 & 16.1 \\
\hline No.21 & 5 & 15.0 & 16.5 & 16.5 & 170 & 17.2 & 16.3 & 16.5 \\
\hline 平场值 & & & $1 \pi .2$ & 17.8 & 179 & 15.2 & 170 & 16.7 \\
\hline
\end{tabular}

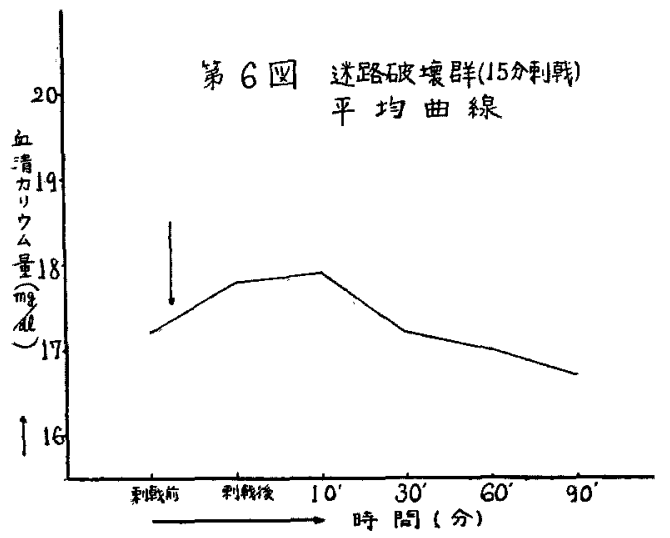

第 2 節 迷路破壊 30 分刺战群

両側迷路を破壊した成犬に 30 分の加速迴䢂刺战を加 えて、その影響による血清 $\mathrm{K}$ 量の消長を筧察した。

実験 23 Ne. 22 \& $10.5 \mathrm{~kg}$

刺㦸前の值务 $\mathrm{dl}, 10$ 分後 $18.0 \mathrm{mg} / \mathrm{dl}, 30$ 分後 $17.4 \mathrm{mg} / \mathrm{dl}, 60$ 分後 17.2 $\mathrm{mg} / \mathrm{d} 1,90$ 分後 $16.7 \mathrm{mg} / \mathrm{dl}$, であつた。動物は少ま疲れ ているように見受けられた。

笑鍳 24 No. 23 \% $9.5 \mathrm{~kg}$

刺㦸前の血清 $\mathrm{K}$ 量は $15.9 \mathrm{mg} / \mathrm{dl}$ であつたが, 刺战 咺後 $16.1 \mathrm{mg} / \mathrm{d} 1,10$ 分後 $16.5 \mathrm{mg} / \mathrm{dl}, 30$ 分後 $16.7 \mathrm{mg} /$ dl と僅かな上刑を示し，60 分後 $16.3 \mathrm{mg} / \mathrm{dl}, 90$ 分後 $16.1 \mathrm{mg} / \mathrm{dl}$ となつた。実験中動物は割合平静であつた。

奉戨 25 No. $24 \quad 6 \quad 12.0 \mathrm{~kg}$

血清 $\mathrm{K}$ 量㤬刺㦸前 $16.3 \mathrm{mg} / \mathrm{dl}$ 刺㦸直後 $16.9 \mathrm{mg} / \mathrm{dl}$, 10 分後 $16.9 \mathrm{mg} / \mathrm{dl}, 30$ 分後 $17.2 \mathrm{mg} / \mathrm{dl}, 60$ 分後 16.7 $\mathrm{mg} / \mathrm{dl}, 90$ 分後 $15.9 \mathrm{mg} / \mathrm{dl}$ と大差なく経過した. 動物 は実験の終に近ずくにつれて疲労の色が相当見られた。

\section{小 括:}

以上 30 分の加速廻転刺战を与立た 3 例の 血清 $\mathrm{K}$ 量 を鼠察したがいづれも殆んど著しい変動は認められず， 迷路破壊犬では加速度刺㦸の血清 $\mathrm{K}$ 量に及ばす影響は 殆んど認め難いことを示した。すなわち以上了例の平均 值は刺㦸前 $16.4 \mathrm{mg} / \mathrm{dl}$, 刺钱直後 $16.9 \mathrm{mg} / \mathrm{dl}, 10$ 分後 $17.1 \mathrm{mg} / \mathrm{dl}, 30$ 分後 $17.4 \mathrm{mg} / \mathrm{dl}, 60$ 分後 $16.7 \mathrm{mg} / \mathrm{dl}, 90$ 分後 $16.2 \mathrm{mg} / \mathrm{dl}$ となつた.なお 30 分後の平均値に特い て僅かな増加が見られたのは，動物の漸増的な疲労ある いは全身消耗によるものではないかと思われた(第 7 表、 第7 図).

第7 表 迷路破填群( 30 分制戟)

\begin{tabular}{|c|r|r|r|r|c|c|c|c|}
\hline N0.22 & 5 & 10.5 & 17.2 & 17.8 & 18.0 & 19.4 & 17.2 & 16.7 \\
\hline N0.23 & 9 & 9.5 & 15.9 & -16.1 & 16.5 & 16.7 & 16.8 & 16.1 \\
\hline N0.24 & 5 & 12.0 & 16.3 & 16.9 & 16.4 & 17.2 & 16.7 & 15.9 \\
\hline 平均1 & & 16.4 & 16.9 & 17.1 & 17.4 & 16.7 & 16.2 \\
\hline
\end{tabular}

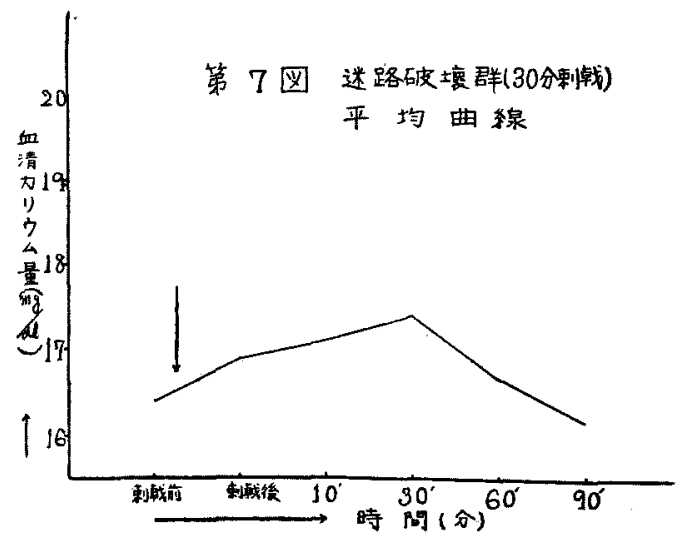




\section{第 3 節 迷路破壊 60 分剌战群}

両則迷路を破壞した成犬に対し，刺㦸時間を更に延長 して 60 分の加速迴転刺㦸を与え，杂の刺皒の血清 $\mathrm{K}$ 量 に及ぼす影響を検討した。

実験 26 No. 25 o $14.5 \mathrm{~kg}$

血清 $\mathrm{K}$ 聂は刺㦸前 $18.0 \mathrm{mg} / \mathrm{dl}$ のものが, 刺㦸直後 $18.4 \mathrm{mg} / \mathrm{dl}, 10$ 分後 $18.8 \mathrm{mg} / \mathrm{dl}, 30$ 分後 $18.4 \mathrm{mg} / \mathrm{dl}, 60$ 分後 $18.0 \mathrm{mg} / \mathrm{dl}, 90$ 分後 $18.2 \mathrm{mg} / \mathrm{dl}$ となつた。動物は 最後まで割合元気であつた。

実験 27 No. 26 。 $12.0 \mathrm{~kg}$

刺㦸前の值 $16.9 \mathrm{mg} / \mathrm{d} 1$ 飞対し, 刺㦸直後 $17.6 \mathrm{mg} / \mathrm{dl}$, 10 分後 $17.6 \mathrm{mg} / \mathrm{dl}, 30$ 分後 $17.4 \mathrm{mg} / \mathrm{dl}, 60$ 分後 $17.2 \mathrm{mg}$ $/ \mathrm{dl}, 90$ 分後は $16.7 \mathrm{mg} / \mathrm{dl}$.であつた. 実験中動物は少々 疲学の色が見られた。

実験 28 No. 27 \% $9.5 \mathrm{~kg}$

刺㦸前 $15.8 \mathrm{mg} / \mathrm{dl}$ に対し, 刺战直後 $15.9 \mathrm{mg} / \mathrm{dl}, 10$ 分後 $16.7 \mathrm{mg} / \mathrm{dl}, 30$ 分後 $16.9 \mathrm{mg} / \mathrm{dl}, 60$ 分後 $16.5 \mathrm{mg} /$ dl, 90 分後 $15.6 \mathrm{mg} / \mathrm{dl}$ と大差なく経過した.

小 括 :

以上 3 例の平均值を見ると, 刺战前 $16.9 \mathrm{mg} / \mathrm{dl}$, 刺㦸 直後 $17.3 \mathrm{mg} / \mathrm{dl}, 10$ 分後 $17.7 \mathrm{mg} / \mathrm{dl}, 30$ 分後 $17.9 \mathrm{mg}$ / $\mathrm{dl}, 60$ 分後 $17.2 \mathrm{mg} / \mathrm{dl}, 90$ 分後 $16.8 \mathrm{mg} / \mathrm{dl}$ であつた.

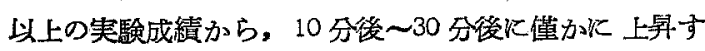
る傾向を示したが他はいづれる著变は見られなかつた。

第 8 表 迷路破液群 (60 分剌戟)

\begin{tabular}{|c|c|c|c|c|c|c|c|c|}
\hline 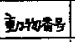 & 性 & 体息(kg) & 敖战前 & 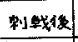 & 10 & $30^{\circ}$ & $60^{\circ}$ & $90^{\prime}$ \\
\hline No.25 & 8 & 14.5 & 18.0 & 18.4 & 18.8 & 18.4 & 18.0 & 18.2 \\
\hline N0.26 & $\delta$ & 12.0 & 169 & 17.6 & 17.6 & 17.4 & 17.2 & 16.7 \\
\hline No.2T & 5 & 9.5 & 15.8 & 15.9 & 16.7 & 16.9 & 16.5 & 15.6 \\
\hline 平枃䛧 & & & 16.9 & 17.3 & $17 . T$ & 17.9 & 17.2 & 16.8 \\
\hline
\end{tabular}

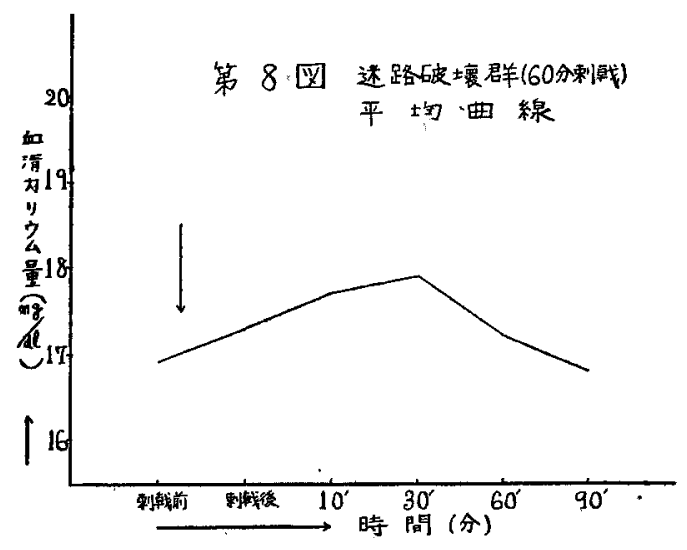

すなわら両側迷路破壊犬に'15 分, 30 分, 60 分間の加速 県転刺㦸を与えても正常群のような著明な変動を示さな かつた（第 8 表，第 8 図）。

\section{第 4 章 重曹注射群}

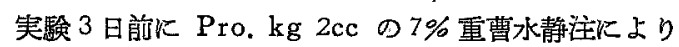
耳石基礎物質を溶解せしめた成犬に和いて，加速迴転刺 战がその血清 $\mathrm{K}$ 量に対していかなる影㗽を与えている かを観察し，耳石の持つ役割を検討した。

第 1 節 重曹注射 15 分刺㦸群

実験 3 日前に 重曹注射をした成大に 15 分間加速迴坛 刺㦸を与え,その变動を観察した。

実験 $29 \mathrm{No}, 28$ 8 $8.5 \mathrm{~kg}$

血清 $\mathrm{K}$ 量は刺㦸前 $17.8 \mathrm{mg} / \mathrm{dI}$ のむのが刺㦸直挠 $18.2 \mathrm{mg} / \mathrm{dl}$ と少しく増加, 10 分後 $18.0 \mathrm{mg} / \mathrm{dl}, 30$ 分後 $18.0 \mathrm{mg} / \mathrm{dl}, 60$ 分後 $17.8 \mathrm{mg} / \mathrm{dl}, 90$ 分後 $17.4 \mathrm{mg} / \mathrm{dl}$ と 徐々に減少し，ほ心刺㦸前の值に復した．実験中動物は 至極平静であつた。

実験 30 No. 29 o $14.0 \mathrm{~kg}$

刺战前の值は $17.4 \mathrm{mg} / \mathrm{dl}$, 刺㦸值後 $18.2 \mathrm{mg} / \mathrm{dl}, 10$ 分 後 $18.6 \mathrm{mg} / \mathrm{dl}$ と僅かな上昇を示し，30 分後 $18.4 \mathrm{mg} /$ $\mathrm{dl}, 60$ 分後 $17.8 \mathrm{mg} / \mathrm{dl}, 90$ 分後 $17.6 \mathrm{mg} / \mathrm{dl}$ となり, 著 しい変化がなかつた・動物は実験中少し疲学しているよ らに見受けられた。

実戨 31 No. 30 우 $12.5 \mathrm{~kg}$

刺战前の值は $19.2 \mathrm{mg} / \mathrm{dl}$, 刺皒直後の值は $19.6 \mathrm{mg} /$ $\mathrm{dl}, 10$ 分後は $19.8 \mathrm{mg} / \mathrm{dl}, 30$ 分後，60 分後は共に 19.6 $\mathrm{mg} / \mathrm{dl}, 90$ 分後は $18.8 \mathrm{mg} / \mathrm{dl}$ で殆んど上舁が見られな かつた・動物は終始平静であつた。

笑騟 32 No. 31 \& $9.5 \mathrm{~kg}$

血清 $\mathrm{K}$ 量は刺㦸前 $18.6 \mathrm{mg} / \mathrm{dl}$ のものが, 刺此直後 $19.4 \mathrm{mg} / \mathrm{dl}, 10$ 分後 $19.6 \mathrm{mg} / \mathrm{dl}, 30$ 分後 $19.0 \mathrm{mg} / \mathrm{dl}, 60$ 分後 $18.6 \mathrm{mg} / \mathrm{dl}, 90$ 分後 $18.2 \mathrm{mg} / \mathrm{dI}$ で著しい増減が見 られなからた・実験中動物は泣いたり，少しく頭を動か したりしたがすぐ平静となつた。

小 括:

4 例の平均值を見ると, 刺㦸前の值は $18.2 \mathrm{mg} / \mathrm{dl}$, 刺 战直後 $18.8 \mathrm{mg} / \mathrm{dl}, 10$ 分後 $19.0 \mathrm{mg} / \mathrm{dl}, 30$ 分後 $18.7 \mathrm{mg}$ $/ \mathrm{dl}, 60$ 分後 $18.4 \mathrm{mg} / \mathrm{dl}, 90$ 分後に付 $18.0 \mathrm{mg} / \mathrm{dl}$, とな りいつれも著しい变動が見られなかつた・すなから予 め重曹注射をなし、耳石基礎物質を溶解せしぬた成犬に 15 分間加速迴転刺战を与えると正常群儿比し，血清 K 量は著しい変化を示さず，加速建檕刺㦸の影響の軽少な ことが諗められた（第 9 表, 第9図). 


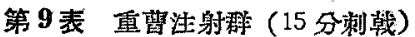

\begin{tabular}{|c|c|c|c|c|c|c|c|c|}
\hline 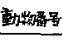 & 性 & 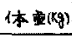 & 刺諓肳 & 俥諓吱 & $10^{\circ}$ & $30^{\prime}$ & $60^{\circ}$ & $90^{\circ}$ \\
\hline N 0.28 & $\hat{s}$ & 8.5 & 17.8 & 1. 8.2 & 18.0 & 18.0 & 17.8 & 174 \\
\hline $\mathrm{N} 0.29$ & $\delta$ & 14.0 & 17.4 & 18.2 & 18.6 & 18.4 & 17.8 & 17.6 \\
\hline$N 0.30$ & 우 & 12.5 & 19.2 & 19.6 & 19.8 & 196 & 19.6 & 18.8 \\
\hline No.31 & 占 & 9.5 & 18.6 & 194 & 19.6 & 19.0 & 18.6 & 18.2 \\
\hline 平场招 & & & 18.2 & 18.8 & 19.0 & 18.7 & 18.4 & 18.0 \\
\hline
\end{tabular}

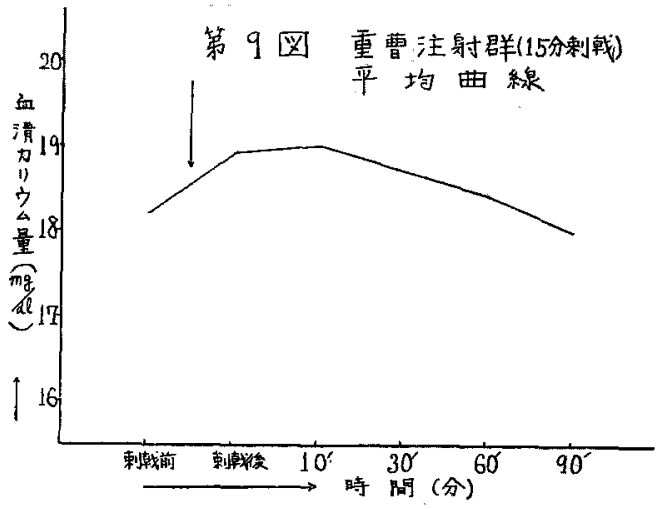

第 2 節 臬曹注射 30 分刺皒群

奏験 3 日前に重曹注射引した成大に，30 分間加速迴転

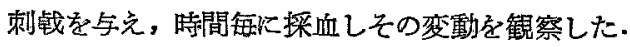

実験 33 No. 32 우 $9.5 \mathrm{~kg}$

刺战前の值は $17.4 \mathrm{mg} / \mathrm{dl}$, 刺战直後 $18.2 \mathrm{mg} / \mathrm{dl}, 10$ 分 後 $18.6 \mathrm{mg} / \mathrm{dl}, 30$ 分後 $17.8 \mathrm{mg} / \mathrm{dl}, 60$ 分後 $17.4 \mathrm{mg} / \mathrm{dl}$, 90 分後 $18.0 \mathrm{mg} / \mathrm{dl}$ となり殆んど呰が見られなかつ た、動物は最後まで元気であつた。

尧跲 34 No. 33 \& $12.5 \mathrm{~kg}$

刺㛺前の値は $19.2 \mathrm{mg} / \mathrm{dl}$, 刺㦸直後 $19.8 \mathrm{mg} / \mathrm{dl}, 10$ 分 後 $19.6 \mathrm{mg} / \mathrm{dl}, 30$ 分後 $19.8 \mathrm{mg} / \mathrm{d} 1,60$ 分倦 $19.4 \mathrm{mg} / \mathrm{dl}$, 90 分後は 19:0mg/dl で，いづれも著しい変化登示さな かつた。動物は終始平静であつた。

実験 35 No. 34 占 $10.5 \mathrm{~kg}$

刺㦸前の值 $20.9 \mathrm{mg} / \mathrm{dl}$ K対し, 刺钱直後は $20.7 \mathrm{mg}$ $/ \mathrm{dl}, 10$ 分後 $21.1 \mathrm{mg} / \mathrm{dl}, 30$ 分後 $21.3 \mathrm{mg} / \mathrm{dl}, 60$ 分俊 $20.7 \mathrm{mg} / \mathrm{dl}$, 90 分後 $20.3 \mathrm{mg} / \mathrm{d} 1$ と䅅過した。動物は最 後をで平静であつた。

\section{小” 括:}

垔曾注射大に 30 分間加速廻転刺㦸を与えた結果，3例 の平均值は, 刺钱前 $20.9 \mathrm{mg} / \mathrm{dl}$ で刺㦸犆後 $19.5 \mathrm{mg} / \mathrm{dl}$, 10 分後 $19.7 \mathrm{mg} / \mathrm{dl}, 30$ 分後 $19.6 \mathrm{mg} / \mathrm{dl}, 60$ 分後 $19.1 \mathrm{mg}$ $/ \mathrm{dl}$ ，90分後 $19.1 \mathrm{mg} / \mathrm{dl}$ であつた。この場合も 15 分周

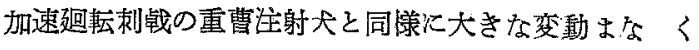

第 10 表 重曹泩射群（30 分剩载）

\begin{tabular}{|c|c|c|c|c|c|c|c|c|}
\hline 重物数品 & 性 & 体配(kg) & 俥蛲前 & 制倿 & $10^{\circ}$ & $30^{\circ}$ & $60^{\circ}$ & $90^{\circ}$ \\
\hline No. 32 & 후 & 9.5 & 17.4 & 18.2 & 18.6 & 17.8 & 17.4 & 180 \\
\hline No.33 & $\delta$ & 12.5 & 19.2 & 19.8 & 19.6 & 19.8 & 19.4 & 19.0 \\
\hline N 0.34 & $\hat{0}$ & 10.5 & 20.9 & 20.7 & 21.1 & 21.3 & 20.7 & 20.3 \\
\hline 平均植 & & & $19-1$ & 19.5 & 19.7 & 19.6 & 19.1 & 19.1 \\
\hline
\end{tabular}

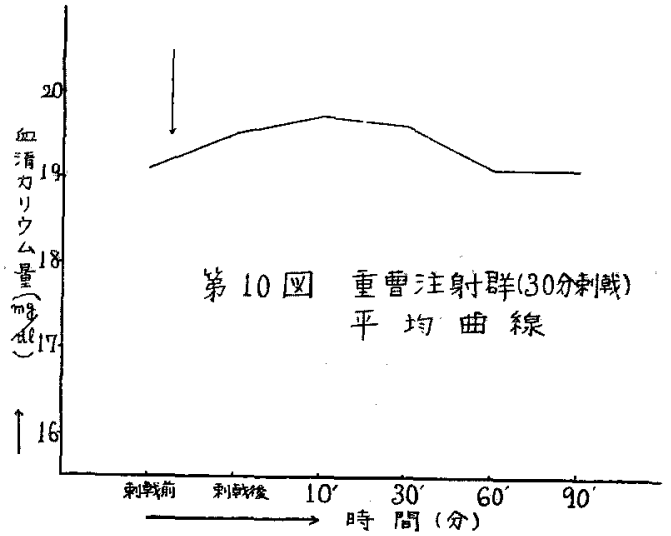

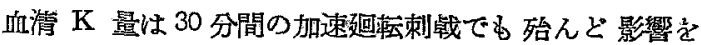
受けないことが钼察された（第 10 表, 第 10 図).

第 3 節 重曹注射 60 分剌㦸群

笑娩 3 日前に予め重曹注射をした成犬に更に 60 分刀

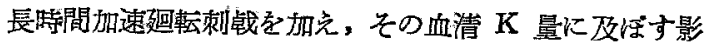
響を検討した。

奏験 36 No. 35 o $15.0 \mathrm{~kg}$

血清 $\mathrm{K}$ 量冲刺战前; $22.1 \mathrm{mg} / \mathrm{dl}$, 刺战直後 $22.6 \mathrm{mg} / \mathrm{dl}$, 10 分後, 30 分後共に $21.6 \mathrm{mg} / \mathrm{dl}, 60$ 分後 $22.1 \mathrm{mg} / \mathrm{dl}$, 90 分後 $21.8 \mathrm{mg} / \mathrm{d} 1$ にはと成り，著明な上眾が見られな かつた．勳物は終始元気であつた。

実跧 37 No. 36 \% $14.5 \mathrm{eg}$

刺㦸前の值は $19.4 \mathrm{mg} / \mathrm{dl}$, 刺战直後 $19.0 \mathrm{mg} / \mathrm{dl}, 10$ 分 後 $19.8 \mathrm{mg} / \mathrm{dl}, 30$ 分後 $18.8 \mathrm{mg} / \mathrm{dl}, 60$ 分後, 90 分後 共に $18.4 \mathrm{mg} / \mathrm{dl}$ を示した。動物はや」元気がなかつ た。

実験 38 No. 37 \& $11.0 \mathrm{~kg}$

刺钱前の血清 $\mathrm{K}$ 最 $18.4 \mathrm{mg} / \mathrm{dl}$ K対し, 刺战直後は: $19.0 \mathrm{mg} / \mathrm{dl}$ 之なり，10 分後 $18.8 \mathrm{mg} / \mathrm{dl} ， 30$ 分後 18.2 $\mathrm{mg} / \mathrm{dl}, 60$ 分後 $18.2 \mathrm{mg} / \mathrm{dl}, 90$ 分後では $17.8 \mathrm{mg} / \mathrm{dl}$, て 刺㦸前後に特記ずべき変動は認められなかった。実験中 勘物は至極平静であつた。

小 括:

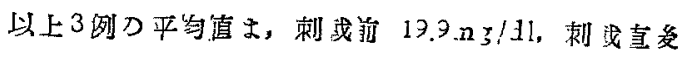




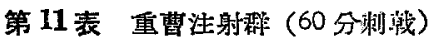

\begin{tabular}{|c|c|c|c|c|c|c|c|c|}
\hline 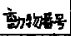 & 性 & 体 $\mathbf{z} ; \mathrm{kg})$ & 俥䛋前 & 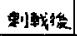 & $10^{\prime}$ & $30^{\circ}$ & $60^{\circ}$ & $90^{\circ}$ \\
\hline N0.35 & 8 & 150 & 22.1 & 22.6 & 21.6 & 21.6 & 22.1 & 21.8 \\
\hline N 0.36 & $\delta$ & 14.5 & 19.4 & 19.0 & 19.8 & 18.8 & 18.4 & 18.4 \\
\hline$N 0.37$ & 8 & 110 & 18.4 & 19.0 & 18.8 & 18.2 & 18.2 & $1 \pi .8$ \\
\hline $\bar{F} \times$ 均1 & & & 19.9 & 20.2 & 20.0 & 19.6 & 19.5 & 19.3 \\
\hline
\end{tabular}

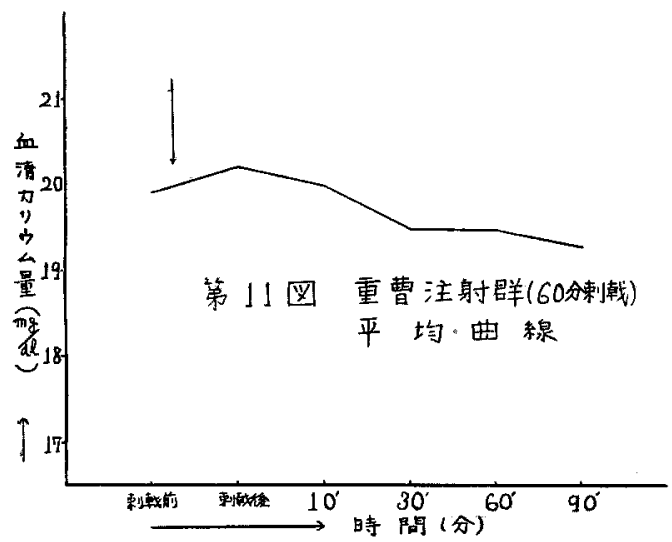

$20.2 \mathrm{mg} / \mathrm{dl}, 10$ 分後 $20.0 \mathrm{mg} / \mathrm{dl}, 30$ 分後, 60 分後忙共に $19.5 \mathrm{mg} / \mathrm{dl}, 90$ 分後は $19.3 \mathrm{mg} / \mathrm{dl}$ を示した. 60 分間加 速迴轱刺㦸の重曹注射大では殆んど変動がなく，あつて も極めて軽微のるのであろうと思われる結果を得た・す なわち重曹注射群は正常群のよう著変袁呈せず。迷路 破培群の場合と同樣に著明な変動は示さなかつた（第 11 表, 第 11 図).

第 5 章 加速廻転刺戟中及び刺戟後の観察

生体の Reparation に䦎する藤崎の主張に従い，刺 皒中及び刺㦸後の血清 $\mathrm{K}$ 量の堌減率を測定し, 加速迴 転中は勿論廻転終了後の生体に及洨す变化の意義判定を 明か心する目的にてこれを実施した。

第 1 節 対昭（固縛採血による）増娍率

成大を加速迴転装置に固縛を行い時間的採血による血 清 $\mathrm{K}$ の堌減率は，4例による平均で固縛直後 $0.56 \%$ の 増加を認わるが 10 分後，30 分後では全く変化なく，60 分後は逆に $2.81 \%$ \% 90 分後では $3.97 \%$ の減少を韵めた が著明な変化は観察されなからた。これを图示すれば第 12 図の如くである(第 12 図).

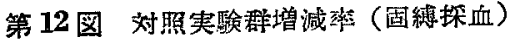

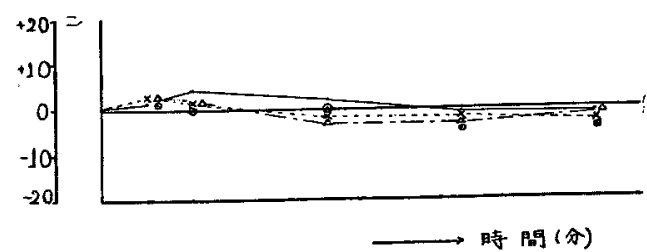

第 2 節 正常群境減㻭

無麻酸の成犬（体重 $10 \mathrm{~kg}$ 前挠, 外耳道, 鼓膜, 值線 運動反射, 向位反射, 跳躍準備反射等の正常, 実秮前 1

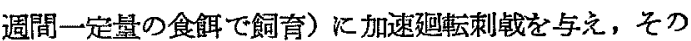
15 分間， 30 分間，60 分間の刺㦸中及び刺㦸終了後の封 間的経過による血清 $\mathrm{K}$ 量の増娍率を観察した。

1. 刺呫期間和の変化

15 分間刺㦸の場合は，刺㦸期間中 $3.53 \% ， 3.22 \%$ ， $6.58 \% ， 2.27 \%$ の血清 $\mathrm{K}$ の増加を認め，4 例平均では $4.02 \%$ の増加率を認めた。

30 分間刺㦸では，3.42\%，13.80\%，12.60\%の3例平 均で 9.83\% の壃加率を算えた。

60 分間刺钱では， $17.50 \% ， 14.0 \% ， 14.60 \%$ の 3 例で 平均 $13.8 \%$ と最高の増加綮方観察された.

2. 刺軲終了後の変化

15 分間刺战の終了後々の平均值を見ると，刺㦸後 10 分で最高值の $10.40 \%$ 宗すが, 30 分，60 分，90 分後と 時間の経過火従い夫を $3.44 \% ， 1.14 \% ， 0.57 \%$ と增加率 は少くなる。

30 分刺战平均值では時間の 経過に 従つて， $5.45 \%$ ，

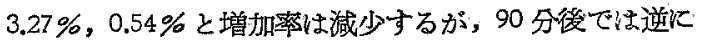
刺㦸前より $-0.32 \%$ の減少率を示した.

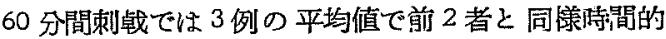
経過徒い7.44\%，1.06\%．0\%と増加率は減少する7j， 刺㦸終了後 90 分では又 $1.50 \%$ と倬か乍ら堌加率の上昇 を認めた。これを図に示せば第13 図の如くになる（第 13 図).

第 13 図正裳群増減浆

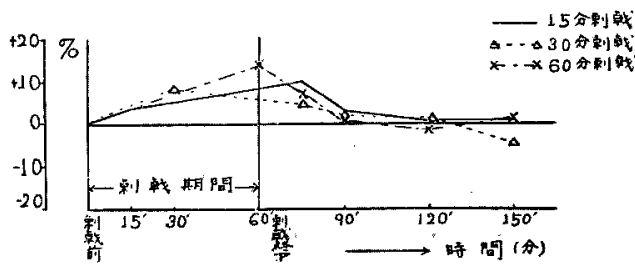

小 括:

以上正常犬群の扣速迴韩刺㦸期間中は, 明らか火血清 $\mathrm{K}$ の増加率上昇が認められる.な特 60 分間刺㦸の增加 率の方が 30 分間刺㦸の場合と比べて期間增加の著しい のは,勿論刺㦸期間の長短によるるのではあるが,前 2 者 は共に刺㦸終了をその增加の㖤として血清 $\mathrm{K}$ は減少す るのに反し，15 分間刺战では終了後10 分でもなお 10.4 $\%$ と最高增加率を呈する。これは生体内の $\mathrm{K}$ 調節に影 
興索与克る因子が多数存在する事亚びに：沉適应症候群 に云うところの Stresor すなわち刺战期間の 長短によ り，生体反応にいろいろの程度の美を生ずることにもよ るのであろうが，刺㦸後は生体の Reparations ersheinung のために, 副交感神経の興舊が併発している事が 重要な因子となつていると考えられる。

\section{第3節 迷路破壊群の増減率}

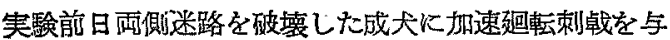
之，その 15 分間，30 分間，60 分間の刺战中及び剌战終 了後の時間的経過に上る 血清 $\mathrm{K}$ 量の堌減率を 篗察乙 た.

\section{1. 刺钱期間中の变化}

15 分間刺钱の 3 例の平均では 3,49\%，30 分間刺战の 3 例の平均で $3.05 \%, 60$ 分間刺㦸の 3 例の平均 $2.37 \%$ を 示し僅かな増加率を喼めたのみであった。

2. 刺战期間終了後の変化

15 分間刺战の場合は，刺战終了唚 10 分，30 分，60 分，90 分を観察すると，夫々平均 $4.07 \% ， 0 \% ， 1.16 \%$ ， $2.91 \%$ を示し，30 分間刺战では $4.26 \%, 6.10 \%, 1.83 \%$ ， $1.22 \%$ の值を示し， 60 分間剌践の場合は $4.74 \% 、 5.2 \%$ ， $1.77 \% ， 0,59 \%$ を示し殆んど著明な变化は認められなか つた.これを曲線にて表わせば第 14 図の如くである（第 14 図).

第 14 図 逃路破填群增減率

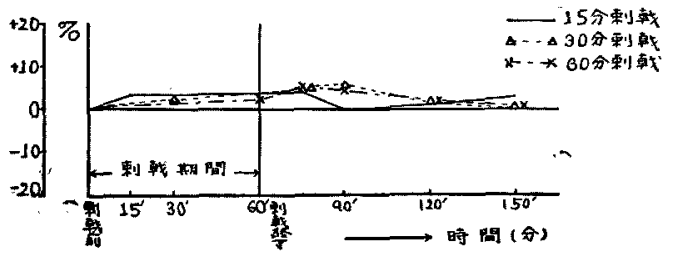

第 4 節 重曹注射群の增減率

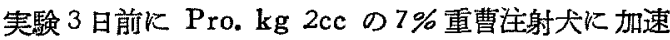
廷転刺战虏与克た場合の増減率は，刺皒期間中 15 分刺 战で $3.25 \%, 4.60 \%, 2.08 \% ， 4.30 \%$ 平均 3.29\% の増加 認め，30 分刺㥂で $4.60 \% ， 3.12 \% ，-0.96 \%$ 平均 2.09 $\%$ の增加を，60 分刺皒では $2.25 \% ，-2.06 \% ， 3.26 \%$ ， 平均 $1,50 \%$ の增加を認めた。な和刺㦸終了後の血清 $\mathrm{K}$ の時間的变化は 10 分，30 分，60 分，90 分索観察する 飞，夫々平均 $4.39 \% ， 2.75 \%, 1.10 \% ，-1.10 \%$ と成り， 30 分間刺战では $3.14 \% ， 2.62 \% ， 0 \% ， 0 \%$ の值を示し， 60 分間刺軲では $0.50 \%,-2.01 \%,-2.01 \%,-3.01 \%$ 々逆に軽度の娍少率を呈するのを観察した。これを図示 すれば第 15 図の如くである（第 15 図）。

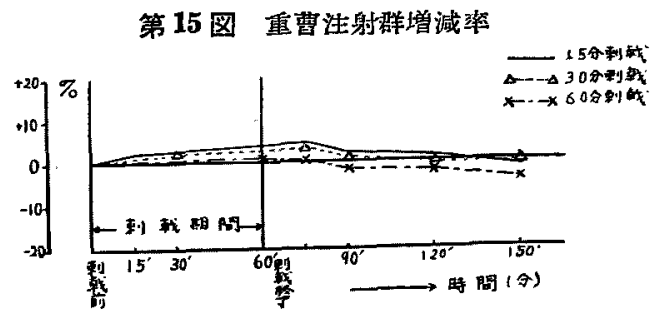

小括:

重曹注射群の血清 $\mathrm{K}$ は，刺战期間中及び刺㦸後多少 の增減率を示すが，その変化に正常群に比して少く，剌 战終了後孔前述の固縛採血対照群の曲線に類似し，迷路 破壇群と同傔殆んど著明な変化は認められなからた。

\section{5. 総括及び考按}

実験成績の総括，無麻酔大学用い，長谷川教授考案の 加速䞟転资置をもつて，15 分，30 分及び 60 分の方速迴 転刺㦸を与え，時間毎に採血し，血清 $\mathrm{K}$ 量をCobaltinitrite 法で比色定量した. また $7 \%$ 重曹水Pro.kg 2cc を静注した成大にも同じ実験を行つた，実験は注射後少 なくとも:2、日上経た成犬で行い，血液その他に及ぼす 重曹水の一過性影響を考慮して血清 $\mathrm{K}$ 量の変動を観察 した.

この観察と平行して，予及前日両側迷路破壊を行つた 成犬についてる同焃な実験を行つた・な扣各群の加速䢙 転刺㦸期間中及び刺㦸後の増減率を測定した。

これ等の実験成績を総括すると，先づ対照実験群の中 採血による影響 4 例を見ると，いつれる著明な变化が認 められずっこれにより血清 $\mathrm{K}$ 量は採血により变動を示 さないことが観察された。また重曹注射による值接の影 響について 5 例の成大で央験を行つた。その結果血清 K 量は注射直後から漸次減少する傾向が見られるが， 24 時間後にはほら゙ 注射前の值に 復することが 観察され た.

正常群の中， 15 分刺钱群 4 例を 見るに，刺战直後よ りも 10 分後最高值を示し, 90 分後には刺㦸前の值に漫 る傾向が見られた３0 分間刺战群3例では，矢張り10 分後急激炕上昇し，以後潮炊减少を見せ刺战前の值に接 近して行く傾向が見られた，次に 60 分刺战群 3 例では 刺战直後最子上昨し, 以後诚少し, 90 分後には刺㦸前 の值に 復した.この血清 $\mathrm{K}$ 量の増加の程度を各群每 に比較すれば，60 分の加速迴転刺㦸を与えた実騟群が 最を堌加し，15 分，30 分の刺战群は，ほ心゙同㴍な増加 文示した。 
10 分後に最る上昇したのに反し， 60 分刺战実験群で は，刺㦸直後に最高值を示したことは興味梁いことであ 3.

これに反し，両側迷路破噮犬においては，加速度によ る迷路刺皒時間の長短に保らず正常群のような血清 $\mathrm{K}$ 量の変化を見す，又 $7 \%$ 重曹水を静注し耳石基礎物質学 溶解した成大に，15 分，30 分，及び 60 分間の剌战を与 之ても，両側迷路破壊大群之同様血清 $\mathrm{K}$ 量の变化怡 んど見られず、認められてる極めて軽度であった．以上 の成綪によりこの実験的西速度病に和ける刺踔感受部 位が主として前庭耳石器官にあること〉重曹注射が加速 度病を䂆防し得ることが実際に認されたと考觉られるの ではなかららか。

血清 $\mathrm{K}$ に就いて

血清塩類としての K の意義はいかなるものであるか を考察するに，血清中の $\mathrm{K}$ は $\mathrm{Na}, \mathrm{Ca}, \mathrm{Mg}$ ，等と共 に陽イォンを形成し，総塩基の一部を占めている：健康 人血清中の総境基濃度は 150 160meq/l (millieqivalent per liter 以下 meq/l と略す) 中, 等当量の除1 オンと平衡しているが，正常血清中の陽イオン分布は pH $7.4 \mathrm{~K} \tau \mathrm{K}^{+}: 5 \mathrm{meq} / l, \mathrm{Na}^{+}: 142 \mathrm{meq} / l, \mathrm{Ca}^{++}$: $5 \mathrm{meq} / l, \mathrm{Mg}^{++}: 3 \mathrm{meq} / l$ である. 血清中の総塩基涍度

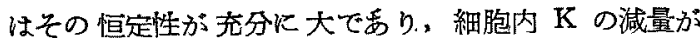
$\mathrm{Na}$ で補われても，血清総塩基平衡飞影響が少い事が知 られている・しかし乍ら Bock（1927）によれば血清の 総壏基量は静脹側では動脈側より $1 \sim 2 \mathrm{meq} / \boldsymbol{l}$ 高値を示 乙，運動によりその 2 倍以上に成ると報告されている。 一方赤血球中では生理的な酸素と孷酸がスの動摇による 塩基の摭散は見られぬし，文水分の堌減によつて塩基濃 度に変化が見られても，血球中の絶対值には変化が起ら ない事が知られている.血清中の総塭基の生理的意義に 関しては, 主として 1. 渗透圧の保持 2. 生理的中和性 の維持 3.筋肉の刺戱性飞対する塩基の相互関係，たと

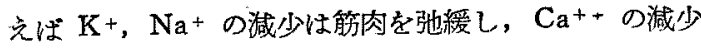
は収縮を強める事等が認められている。

血清 $\mathrm{K}$ の正常健康人温度は $16 \sim 22 \mathrm{mg} / \mathrm{dl}$ で, 細胞 の体謝殊に糖代謝に関係があり、筋肉に生じた乳酸は $\mathrm{K}$ となつて血中に流出し，肝臓て Glycogen が形成され るに従つて血中より減少, 肝臟に蓄積される・肝葴から

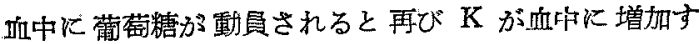
る. 又 K は筋肉の機能に関係がある事は前述したが Stewart（1940）は低 K 血症の時は筋肉の被刺战性が 高まる事を心電図により証明し，Fenn（1940）は K
の減量は筋肉の弱化をきたし，更に進をと麻瘦と成り， 呼吸筋にこれが起ると死亡すると報告. 更に $\mathrm{K}$ の代謝 は他の電解質と比べて複雉ですり，それは $\mathrm{K}$ の血清澧 度が摄取と排浛の外以細胞内外の分布変化及び内分泌機 能により影響せられているからであると述べている。

$\mathrm{K}$ は細胞内に偏在しているので微量の細胞外の移動 す血清 $\mathrm{K}$ 量に大きな変化を与光, 又 $\mathrm{K}$ の腎臟に括け る Clearance 洞一生体でる每日異なつて和り，而か も $\mathrm{Na}$ と巽り常に腎から排泄されている. 又 Selye (1952) 等により K の調整には副腎路質の内分泌機能 が関係して括り，更に自律神経系も大きく関与しておる そ言う報告に梁く興味を抱いている。

聿験成績に対する考按

私の行つた実験成績を，生体に働く刺軲の強さや持 続特間により，生体の反応に種ふな相があると唱える Selye の Stress 説汇照合して考察する. Selye 1936 年英国科学椎誌 Nature 他発表以来，一連の Stress 説 そ続報している.すなわち生体に各種の刺钱作因（Stressor) 例妄ば物理的（䓡, $\mathrm{X}$ 線照射, 音, 光) 化学 的 (酸素, 炭酸ガス, 薬物) 生理的 (栄盖失調, 中毒, 細菌感染, 外傷, 肉体疲労) 精神的 (緊張, 混乱) 作因 等吕加兄られると，生体は本質的に同一な症候群を惹き 起す そしてこの際生体の全身㶤現和れる非特異的な反 応を一括して全身適応症侯群 Generl Adaptation Syndrom (G.A.S.) と定義している. 更に局所に 直接の

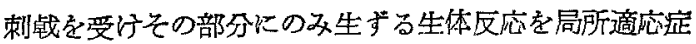
候群 Local Adaptation Syndrom (L.A.S.) と区別 している.時間的経過による G.A.S. の分類は，先づ一 過性の警告反応を生じ，若し Stressor が長特間におた つて加称れば, 更に 2 つ明膫な璟期を経て変化し，抵 抗反応, 疲学反芯と計 3 期の典型的反応を呈すると発表 した。

1) 鳘告反応期

この時期は生体が突然に Stressor 飞曝されて生じた 非特晎症状の総和であり，生体が制㦸仁刘して適応状態 の獲得を得ていない時である.この非特異症状を性質に よつて分類し，i）極く受身である傷㕩あるいはショッ クの徵候 ii）傷害に対する積板的な防衛症候とを述へ ている.良って Stressor が徼烈又は微弱であり過ぎな い典型的な場合は，次の 2 相に区分される。

i）ショック相：これ怔前記 i）に区分されるもので， 急激に加えられた Stressor に対して，生体内より積極 的な反応の認ぬられ《時期であり，単なる受题的傷害の 
現われである.体温降下, 低血圧, 低血糖, 神経采活動 抑制, 筋緊張減遍, 血液濃縮, 毛細管と細胞膜透過性減 退, 異化的な組織破壊, Acidosis, 白血球の減少に続く 增多,Eosin 好性球と淋巴球淢少等である.

ii）反ショック相：前記 ii）飞相当するもので i）上 り移行する.この相の特長は生体のショックに対する積 極的な防衛機序を営さ反応である，即ち副腎皮質は肥大 し, 分泌劣進する。これに反して胸腺淋巴器官は急激 に萎縮障碍される・ショック相に影われた賈化は, 逆の 方向へ進むよ5に成る. 体温血印の上戒，血糖値の增 加, 神経系の活動迲盛, 筋緊張の増大, 血液䁷の増加, 毛細管と細胞膜の透過性昂進, 組織破䘫の停止, Alkalosis を呈する.白血球は引続いて増加し，Eosin 好性 球と淋巴球は減少する・反ショック相には生物がある Stressor に曝された場合, その非特異的防衛反応がこ の反ショッタ相に迄撻していると，その際新たに生物に 対して他の Stressor が加えられても，この新たに加え られた刺㦸素因に対しては生体の抵抗力が増加している

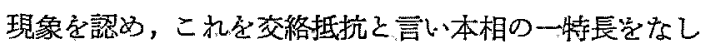
ている・斯のような变化は Stressor が加えられてから 48 時閒以内に顕われ Stressor の稙類とは無関保で一定 の形式の下に起り，下垂体一副腎系の活動によるもの 々推察される.

2) 抵 抗 期

生体に備わつた適応能力は, 長期間 Stressor に懪さ れる依により，警告反応期を経過し，て個体は順灾を得， 種々の非特異的な全身性反应を起してくる.その総括を もつて抵抗期をあらわす，本䝷的汇は反ショック相の延 長で，抵抗性は次第に上昇する.この特期にはそれ迄減 少していた副腎皮質の脂留量が回復するのみならず，場 合火より Stressor が加えられる以前より増加する・同 期炕副㹂发質の実質細胞む堌加し，重量の堌加を認め る. しかし.乍らこの抵抗期に他の Stressor が加わつた 場合，それ対する抵抗力は丁度反ショック相の特長と 反対逆に弱まつている.これを交絡感作々呼び他の Stressor に対する抵抗力を犠牲にして一つの因子に対 して順応抵抗する.

3) 疲労期

Stressor が長期間持続すると，全身の摘応反応は， 抵抗期よりこの疲労期に移行する. Stressor がある程 度以上飞強くなると適応反分を維持しきれなく成り，生 体の適応ェネルギーには限宽が岕るために個体の能力が 消耗しきるのである。この疲労期に観られる变化は殆え
ぞ警告反応の初期・ショック相の变化と類似する・たと 壳ば体温血圧の降下，胸腺淋巴管の菜縮，抵抗期に增加 した副留皮啠の脂頃の再度消失であり，この疲労期の終 末は生体の死至る。

以上の如きSelye の説と著者の動物実験成績とを検 討すると，ある程度一致した成績を見出している。併し 乍らこの説より思考される禁は，刺㦸時間の量的長さで ある. Selye は警告期で 1 48時間，抵抗期では 48 時 間以後, 疲学期は 2 力月以上と云5㭙間定举げている. すなわら胿閏的経過に主腿を置き，そのStressorの大 きさ，䅜類等については䣋しく触れていない点を見る と Stressor が一定でないよ5に思われる。これに反し て著者の䒠験は，長谷川教授の考案になられた特製の加 速迴転装置を用いて夷施し，每分 45 迴転で一定の往復 回転運動そ繰返すために時間により加速度刺战量を一定 にする事が可能であり，その刺㦸因子は時間 (T) と持 続的な強い加速度力 $(\mathrm{G})$ との相乗積に該当する強力な 作用を及ぼし，Selye の施した刺㦸量を遥か伦上迴る ものではいかと考える、故汇必ずしも Selye の提唱 している方式と完全には一致しないが，加嗃度刺㦸を一 種のStressor と見做した時，迷路を刺战して種々の生 体反応を起させるという特殊の条件のほか, 殆んど符合 する所である.これにより加速度刺钱学一定した Stressor と考光れば，この加速度刺㦸によつて起る現象か， ら, 所謂 Selye の言う警告期, 抵抗期, 疲期労期の三 期に該当するのではなかららかと思われる実験成績を得 ている.

寸なわち 15 分間刺战を 与えると血清 $\mathrm{K}$ 量は一過性 の著明な上昇学示すので警告期であり，30 分間刺㦸は 前者とは異る上算を示すが漸次減少する傾向が見られる ので抵抗期に相当し，60 分閒刺㦸は最も著明な上昇を 示すので疲学期に入るるのと考えられる. 併し Selye によると Stress による血中，尿中の $\mathrm{K}$ 量は警告期に 著明な上犁を示し，抵抗期には減少を呈し，疲労期には。 上年する傾向にあると述べている.今回の実験成績によ り加速度刺戟学与党ると動物は疲労堂きたし，これによ り体力の総ての反応弆促し，所謂抵抗期，疲学期泪当 する生体反应を若起するのではないかと言う事を考光合 す時, Selyeの説と全く一致しなくともある程度符合し た反応曲線を示していると思われる・併しこの事は加速 度刺㦸を一種の Stressor そ見做した場合にの及理論つ けられるすのであり，加速度刺战は飽く迄 Stressor と して方式的に趣を異にするむので，その結果多少共異な 
る所があるの垱然の事であると考党られる。

次に加速度病に自律神経と密接な関係を持つている。

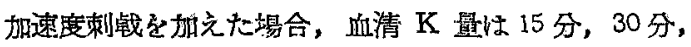
60 分間の刺㦸に対していづれの埸合る相当の增加が認 められた。. Selye によると生体に Stressor そ加光た埸 合，血清 $\mathrm{K}$ 量は上抙するがこの機転に関しては副腎の Adrenalin の分泌作用が重大な役割を演じ，該分汹作 用が强い程，血清 $\mathrm{K}$ 量の増加が著明になると述べてい る. 鹉副によると正常家東に過敏性ショックを加えた

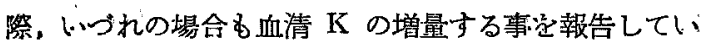
る.教室の長尾は正常犬に加速度刺㦸を加えた場合，血 中 Adrenalin 量はいつれる相当の增加を示すと報告

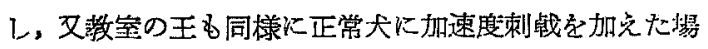

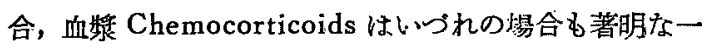
過性の上昇を示すと報告している.加速度病は迷路を介 して起る交感神経緊張性の自律神経譏能障碍と考克られ ているが，前記の諸所見によりこの見解を妥当とするも のである・

加速迴転中の 血清 K の将化は第 16 图に示す通りで ある(筹16図).

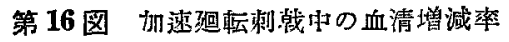

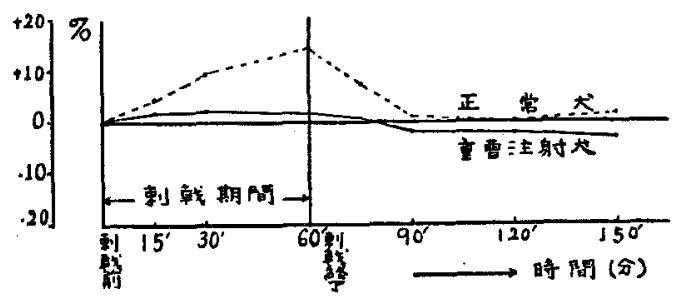

この曲線は Selye の報告している Stress 時に和け るKの曲線によく似て扣り，殊に抵抗期，疲学期治殆 んど符合している（正常犬君境合）.

同門諸先輩による実䍄加速度病一連の研究を省て, 加 速迴㶿刺戱中は血清中の Adrenlin, Cholin esterase, 血獎蛋白は殆えど同椂な増加曲線を示すのに反て，Cholesterin, $\mathrm{Ca}$ ，は殆えど同様な減少曲線索示す 又 Vita・ min $B_{1} は$ Adrenlin $に$, Vitamin A, 血糖, Chemocorticoids は Cholesterin によつた曲線尗示し，前 者, 後者群は夫ょ一つの形成をるつて変化して行く. 加 速迴坛終了後の各成分の変化は，刺㦸終了後 10〜20 分 を堌加あるいは減少の極として次第に元に復与る・併し 乍ら刺㦸中 Adrenalin と同樣に増加した Cholineste-

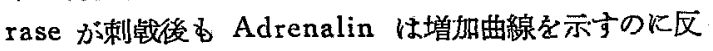

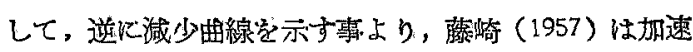
廻転刺㦸中は明らか火交感神経緊張性の自律神経障碍を 起すのであるが，刺钱後性生体の Reparations-ersheinung が顕れると述べている，以上の筧点から血清 K

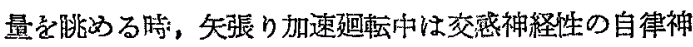
経障碍をきたし，刺㛺後には生体の Reparation の一 関としての現象が認められるものと思われる。唯こっで

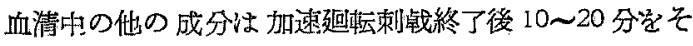
の極として变化するに反し，血清 $\mathrm{K}$ は刺战終了後直ち

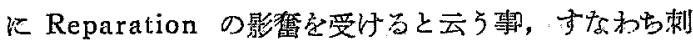

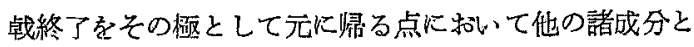
以特異小媇化と思和れる。

迷路破壊と副腎との関係

次に迷路破壊咥物之副腎との関係については Ceni が

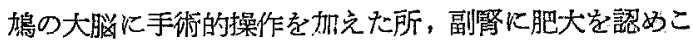
の原因を自律神経中枢の刺㦸によると報告して以来，迷 路と副餐についての研究が行われている、すなわち西 端，原田は沜で片側迷路を破壊すると手術挠 1 週間前後 には2〜4倍に達する副腎重量の増加を認めると報告し ている.これに対し瀬尾は同しく片測迷路夻破壞した沜

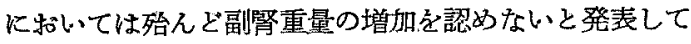

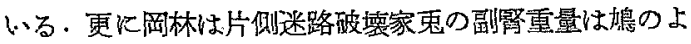
うに顕著でなく，その嬶加率は $7.17 \%$ であると報告し ている、これ等の報告から值らに迷路破罜動物と副腎つ 分泌之の相丝関係を直接的儿検討寸る事は不可能である が，私の実鈳から両側迷路破壊犬ては，正常犬のような 血清 $\mathrm{K}$ 量の著明な変化は示さない事が䋩察された。

重霄注射に就いて

生体に加速度刺钱が加放ると加速度病を発生するが， これに対 1 言濃度重曹水の多量静脈内注射がその予防に 有効であることは既に多数の動物並びに人体害験に括け

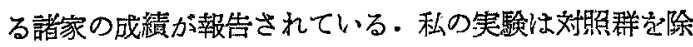
き，注射後少なくとも 2 日以上程た成大に上つて行い，

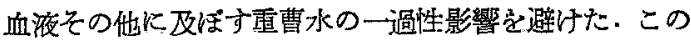
重曹水注射によつて耳石の基碟物質が溶解された成犬に 15 分，30 分，60 分間の加速迴転刺㦸を与方ても血清 $\mathrm{K}$ 量は著明な变動䈍めなからた.すなわち重曹注射犬で

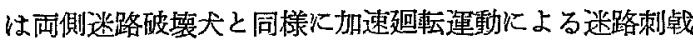
を感受し難くなること艾認めた。徉つて重整水静注の效 果が確められ，且つこれ等の諸現象は迷路そ介して起さ れることが証明された。

偖て高濃度重曹注射つ作用機序に就いては，彷来幾多 の研究の絬果これが耳石を溶解し，平衡斑に括げる加速 
序刺战の感受き阻止するものと考えられてきた。次で Giaccai 等によつて耳石の炭酸カルシッム結晶は重曹 水注射後すな和存在すると報告された. 又島本はメニ ル氏病発生の一原因として，内耳淋巴液中のカリゥムレ ベル維持機転の障碍殊にその増加觉指摘し，内淋巴夜中 にカリゥムが増加する事によつて, 瞱最, 耳鳴等の徴候 学誘発するものと考光，そして及その点に立脚して牟田 等は重曹水注射によるナトリゥムイホンの增加が二欧的

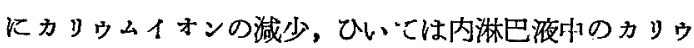
ムイオンの減少を類推し，それによつて重曹水注射がメ ニェル氏病あるい、泇速度病予防洨果があるすのとし ている、しかし乍ら内淋巴液中のナトリッムイオンの增 加, カリゥムイオンの減少によつてのみ, 前庭終末部位 の感覚機能低下そ類推する事は直ちに認知し得ないるの である。

すな和ち（1）重曹注射によりカリゥムイオンの減少 して恢復する迄の時間が比較的速かであり，第2図に観 察される如く 24 㭙間後には汪ら注射前の值に復する。

（2）ところが臨床的にも実験的にも，重曹注射によつて 得られる比較的良効々言 5 予防期間が，少くとも 3 力間 証明されている. (3) 内耳淋巴液の中にカリゥム減少に よる感党機能低下が起るものとすれば, 前庭のみならず 半規管あるいは蝸牛亮の力の終末部位であり,クブラ コルチ氏器官の 感覚機能低下す当然起すべきものであ る. (4) 重曹注射した後で一時的に内耳の機能低下を思

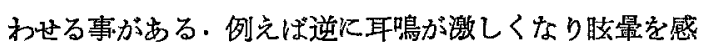
ずる事もあるが，少くとも5〜10 分で消退する．これは 内耳淋巴中の一腈的に生じたカリウム減少が，恢復する 迄の時間と割合に良く符合するものと思われる。

最近の長谷川教授の研究では耳石の一部分である炭酸 カルジウムの結晶を取り囲む耳石基碟物質が重曹水によ つて溶解され，炭酸カルショムの結晶の周团に慣性の働 に対する緩衝相が，加速庋刺战の感受を消失又は軽减す ると考えられるに至つた。高濃度重曹水注射作用の基碟 的研究就いては次の諸氏によつて報告されている・す なわち血液の变化に就いて，教室の光岡は一過性の炭酸 ガス含有量の上昇を，田辺は血液水素イオン濃度の不変 なことを，松山は血梼の一過性の減少を，鈴木はカルシ ウムの増加, 泉はナトリウムの増加と総㔻白減少及び ルブミン・グロブリン比低下を報告した。前田は血清比 粘䅌庭の低下を観察している・尿えの影響では松山は相 当なアルカリ側觉の移動が示されクロール量は增加し 糖蛋白の变動認められなかつたことを発表している。
论で藤崎，松山，前川，鈴木，後藤等に上り重曹注射の 血管壁えの影響が観察され，重曹水注射による末梢血管

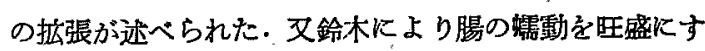
ることが認められた．藤崎による頸部交感神経節除去， 頸動脈洞神経摘出, あるい:調圧神経切除等を行つた異 常頭位眼浱動物の脳血行所見より，重曹水注射が血管緊 縮の緩解の他に又血管弛緩の恢復にも㗢くことが明が された. 又松山等により重曹水注射による血管痤緎緩解 が認められ，高濃度重曹水の特異性が報告された．古代 は眼球運動に及汪す影響として，回転性眼振には影響せ

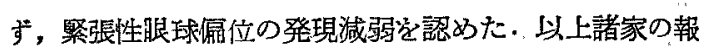
告々加速度庆に和ける血液及びその他の諸变化とを考察 する時, 非常に刘称的である事は, 高濃度重曹水注射の 加速度病予防を理論的炕裏付けるるのとして甚だ與味梁 い問題である。

以上の筧察及び 従来の 諸先䧳の 研究業績より参照し て, 交感神経緊張性の自律神経失調の一つである実験的 加速度病を無麻酔成犬により実験し, 血清 $\mathrm{K}$ の刺钱期 間帆増加する事は加速度の迷路刺战に原因し，重曹水 静注が加速度病の予防化著效を有すると言われる長谷川 教授の説に一致するものであると思われる。

\section{6. 結 語}

長谷川教授の考案になられた特製の加速迴転装置そ用 いて，その加速度による迷路刺㦸が血清カリウムに及ぼ す影響並びにこれに対する高濃度重曹水注射の効果に就 い観察した・すなわち無麻酔犬を用い正常犬，両側迷 路破坮犬，重曹注射犬群に分ち，15 分，30分，60 分間 加速廻転刺钱を加光，時間每に採血し，Cobaltinitrite 法で比色定量し次の結果艺得た。

1）正常犬に 15 分，30 分，60 分間の加速迴転刺㦸を 与えるといられも著明な一過性の上昇を示した。すなる ち血清 $\mathrm{K}$ 量は 15 分間の刺㦸では刺战直後より10 分後 までた， 30 分，60 分間の刺战では刺㦸直後に夫ょ增加 を示した. 以後は時間の経過と共に輠次減少している。 又 60 分間の加速迴転刺㦸によつて最高の増加を示した.

2）両側迷路破罱犬に 15 分，30 分，60 分間の加速迴

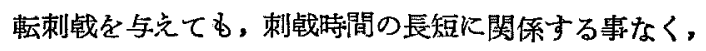
いられる殆んど変化を示さなかつた。

3）高濃度重曹注射大に括いてb加速廻転刺战によつ て, 両側迷路破壊犬と同様に明かな变動を示さなかつ た。

4）な拉各群の加速迴転刺战中及び 刺战終了後の 血清 $\mathrm{K}$ の増減率を比輘測定した. 
以上の実験成績から，加速迴轱刺歧が迷路を刺㦸し恐 らく交感神経緊張性自律神経作用のもとに血清 $K$ 量の 変化芑きたすと思われ，又高䃩度重曹水静脈注射がこの 血清 $\mathrm{K}$ 量の変化を阻止した事は，重曹水注射吕加速度 病の䂆防に著效学有する一つの表われとす思われる。

\section{7. 参考文献}

1) Hasegawa. T.: Arch. of Otol. 50; 1949.

Starken Stein: Die Seekrahkheit. Klemperers Neue Deutsche Klinik. Bd. 9; 1932.

3) Fabio

Giaccai \& AldoCarle: Arch. of Otol. 4; 1951. 4)

Dieckmann, W.J.: Toxiemias of Pregnancy. The C.V. Mosby. St. Louis; 1952.

5) Dieckmann \&

Wegner, C.J.: The Blood in normal Pregnancy Arch. Int. Med. 53; $1934 . \quad$ 6) Albers, H.: Kolloide, Electrolyte u. Hormon Leipzig; 1943. 7) Rosenbeck, H.: Bioch. Z. 208; 1929. 8) Rosenbeck, H.: Arch. f. Gynäk. 145; 1931. 9) Berg-qvist, N.: Am. J. Obst. \& Gynec. 635; 1952.10$)$ Tena Molera: Zbl. f. Gynäk. s. $600 ; 1937$. 11) Seitz, L.: Grundlagenforschung der normalen und toxischen Schwangerschaft. Biol. u. Path. d. Weibes: $635 ; 1951$. 12) Selye, H.: Clin. Endocrinol. 6; 117 ; 1946, 13) Selye, H.: Textbook of Endcrinology; 1946. 14) Selye, H.: J.A.M.A. 144; 1353; 1950. 15) Selye, H.: The Story of the Adaptationsyndrom; Acta. Montoreal ; 1952. 16) Fujisaki, S.: Uber den Einfluss des Labyrinthreizes auf die Funktion des autonomen Nervensystems. Berichte des VI internationalen Kon* gress für Otolaryngologie；1957. 17) 長谷川高

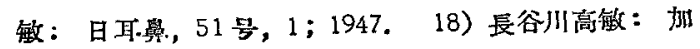
速度病；1948. 19) 是谷川高敏：臨佧, 1 忩, 1 号; 1948. 20) 長谷川高敏：臨朱, 2 㣰, 1 号； 1949.

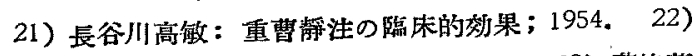

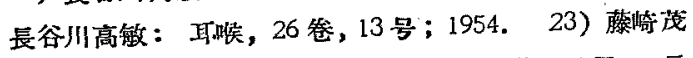

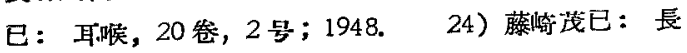

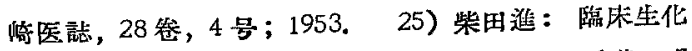
学入阴；1953. 26) 山田与一: 最近医学, 6 替, 7

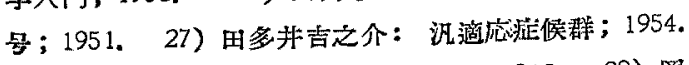

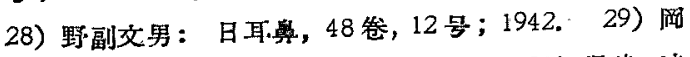

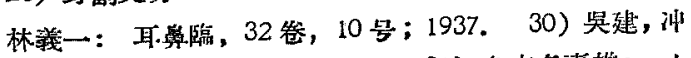
中重雄：自律神経系；1944. 31) 島本多喜雄： ‘

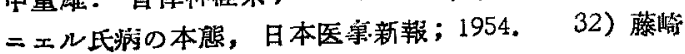

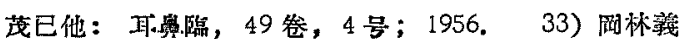

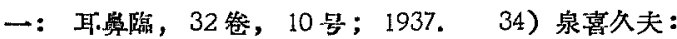
日耳祭, 53 卷, 11 号; 1950. 54 卷, 9 号; 1951. 35) 伊果交雄：日耳-孟，49卷，6昘，10号；1943. 36)

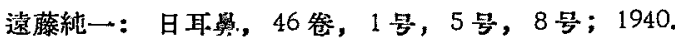
37) 大川內勝治：日耳悬，54焱，1 묵，2 묵；1951,

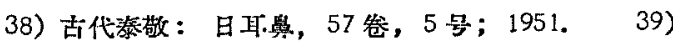
斎藤正行：光電比色計による臨林化学 検查法：1953.

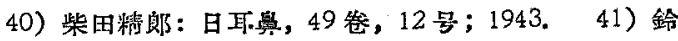
木直唡：阪市医，1卷，3号；1952.2 卷, 2 号；1953. 42）虬尾檤: 副督皮質ホルモン；1953.43）古川隆

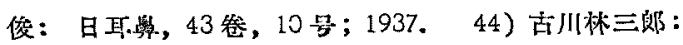

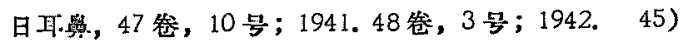

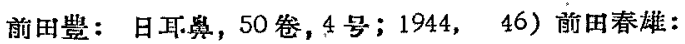
阪市医，3卷，3号；1954.47）松山三千繼：阪市

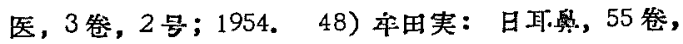

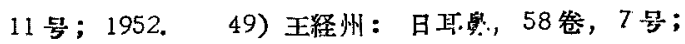

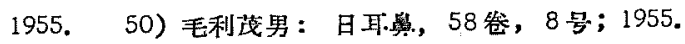
51) 長尾政明：日耳悬，58卷，5昂；1955. 52）光

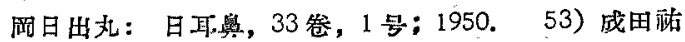

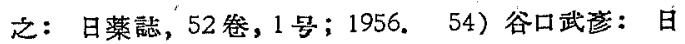

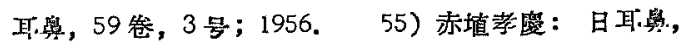
59 然，3㕺；1956.56）上善敏雄：日耳奥，59卷， 4 号；1956. 57) 山川嘉明：日耳.感, 59 卷, 6 旦; 1956. 58) 松山三千線：日耳.鼠, 59 卷 4 등；1956.

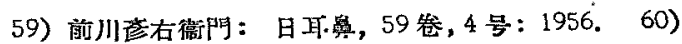
堀內邦夫：日耳.悬，60卷，11号；1957. 61) 吉棫 言人. 生化学, 26 卷, 3 号；294.62) 山本清：生

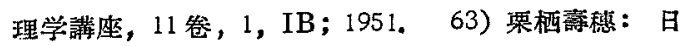
医放線会䛱，15焱，5号；1955.64) 栎条静夫：日 消機苪誌，52 卷，6号; 1955.65) 富田龍夫: アレ

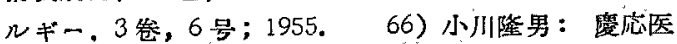
学, 52 卷, 11 号；1955. 67) 小林博子：新潟医学 会誌，68卷，11号；1954.68）原島進：日新医学, 40 卷, 10 号；1953. 69) 相旸光：丙科宝函, 2 卷, 1 농 ; 1955.

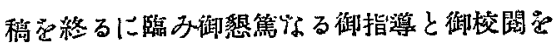

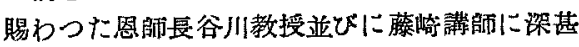

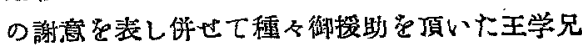
に深く感謝致します

本論交の要旨は昭射 32 年 5 月 19 日第 88 回 日本正鼻咽喉科学会大阪地力会において吐表し I:

（原穕到着＝昭和 33.1.31 日一急載） 